DOI: 10.34015/2523-4552.2021.3.04

УДК 343.431

Андрушко А. В., доктор юридичних наук, доцент, професор кафедри кримінального права та процесу Ужгородського національного університету ORCID: 0000-0002-7735-789

\title{
ОБ’ЄКТИВНА СТОРОНА ТОРГІВЛІ ЛЮДЬМИ
}

У статті досліджено проблемні аспекти об'єктивної сторони торгівлі людьми та на цій основі сформульовано пропозиції, спрямовані на вдосконалення чинного кримінального законодавства.

Ключові слова: кримінальні правопорушення проти волі, честі та гідності особи; торгівля людьми; об'єктивна сторона кримінального правопорушення; уразливий стан.

В статье исследованы проблемные аспекты объективной стороны торговли людьми и на этом основании сформулированы предложения, направленные на усовершенствование действующего уголовного законодательства.

Ключевые слова: уголовные правонарушения против свободы, чести и достоинства личности; торговля людьми; объективная сторона уголовного правонарушения; уязвимое состояние.

Постановка проблеми. На жаль, проблема торгівлі людьми продовжує залишатися злободенною. У зв'язку з цим актуальним $\epsilon$ пошук ефективних шляхів кримінально-правової протидії зазначеним посяганням.

Аналіз останніх досліджень та публікацій. Проблеми відповідальності за торгівлю людьми у науці кримінального права досліджені доволі глибоко. Зокрема, варто згадати праці В. І. Борисова, Н. О. Гуторової, В. О. Іващенко, К. М. Іскрова, В. А. Козака, Я. Г. Лизогуба, О.В. Наден, Д. О. Негодченко, А. А. Нєбитова, А. М. Орлеана, В. М. Підгородинського, А. С. Політової, М. І. Хавронюка та інших науковців. Разом з тим, попри значну кількість праць, присвя- чених проблемам відповідальності за вказаний злочин, більшість відповідних питань залишаються дискусійними. Крім того, необхідно враховувати, що більшість цих праць опубліковані в період чинності перших двох редакцій ст. 149 КК України (нагадаємо, що 6 вересня 2018 р. зазначена стаття знову була викладена у новій редакції).

Постановка завдання. Мета статті - на підставі аналізу спеціальної літератури та судової практики дослідити проблемні аспекти об'єктивної сторони торгівлі людьми та на цій основі сформулювати пропозиції, спрямовані на вдосконалення чинного кримінального законодавства.

Виклад основного матеріалу. 3 диспозиції ч. 1 ст. 149 КК України 
випливає, що з об'єктивної сторони торгівля людьми може вчинятися у таких формах: 1) торгівля людиною; 2) вербування людини; 3) переміщення людини; 4) переховування людини; 5) передача людини; 6) одержання людини. Торгівля людьми має місце у разі вчинення хоча б однієї з перерахованих дій.

Стаття про відповідальність за торгівлю людьми в кримінальному законодавстві України з'явилася завдяки імплементації норм міжнародного права. У зв'язку з цим зауважимо, що в міжнародно-правових актах (зокрема, в Протоколі про запобігання та припинення торгівлі людьми, особливо жінками і дітьми, та покарання за неї, що доповнює Конвенцію ООН проти транснаціональної організованої злочинності (далі - Палермський протокол) [1], та в Конвенції Ради Європи про заходи щодо протидії торгівлі людьми [2]) поняття «торгівля людьми» охоплює здійснювані 3 метою експлуатації вербування, перевезення, передачу, приховування або одержання людей. Таким чином, формулюючи диспозицію ч. 1 ст. 149 КК України, законодавець поєднав міжнародно-правове розуміння сутності торгівлі людьми з такою формою даного злочину як власне торгівля людиною.

У юридичній літературі тривають дискусії стосовно першої форми розглядуваного діяння - власне торгівлі людиною. Тут варто зауважити, що у первісній редакції ст. 149 КК України вживалося інше формулювання («продаж людини»), яке не дозволяло притягати до відповідальності за дії, що полягали у купівлі людини. У зв'язку з цим у кримінально-правовій літературі слушно зверталася увага на однобокість від- повідного підходу [3, с. 59-60; 4, с. 10; 5, с. $41-43 ; \quad 6$, с. $101-102, \quad 106]$. Я. Г. Лизогуб та С. С. Яценко, приміром, з цього приводу підкреслювали, що «лише за наявності купівліпродажу людини можна вживати поняття “торгівля", оскільки якщо $\epsilon$ торгівля, то повинні бути як мінімум дві сторони, взаємопов'язані щодо вирішення питання про відчуження i придбання чого-небудь або когонебудь» [5, с. 43]. Однак навіть після того, як законодавець вніс до ст. 149 КК України відповідні зміни, окремі дослідники продовжують стверджувати, що під власне торгівлею людиною слід розуміти тільки ії продаж $[7$, c. $173 ; 8$, c. $312 ; 9$, с. $286 ; 10$, с. 64 , 65].

В кримінально-правовій літературі власне торгівля людиною зазвичай трактується як вчинення щодо людини договору купівлі-продажу $[11$, с. $81 ; 12$, с. $263 ; 13$, с. $115 ; 14$, c. $282 ; 15$, с. $443 ; 16$, с. $384 ; 17$, с. 309 ; 18 , с. $290 ; 19$, с. $30-31]$. При цьому одні автори вважають, що у таких випадках йдеться про передачу або отримання людини за певну грошову винагороду [11, с. $81 ; 12$, с. $263 ; 14$, c. $282 ; 17$, с. $309 ; 18$, с. $290 ; 19$, с. 31 ; 20 , с. $27 ; 21$, с. $342 ; 22$, с. 11 ], інші ж вказують на те, що людина може передаватися чи одержуватися не тільки за грошову винагороду, а й шляхом обміну на коштовності, дорогоцінні метали чи певне майно [16, c. $384 ; 23$, с. $156 ; 24$, c. 23 ; 25 , с. $98-99$; 26 , с. $166 ; 27$, с. 113$]$. Друга точка зору не видається переконливою, оскільки, на наш погляд, в разі обміну людини на коштовності, певне майно тощо має місце не договір купівліпродажу, а договір міни. Зауважимо також, що згідно із ст. 655 Цивільного кодексу України покупець зо- 
бов'язується сплатити за майно (товар) певну грошову суму, а не коштовності чи майно [28].

Стосовно розуміння власне торгівлі людиною у спеціальній літературі трапляються й інші точки зору. Так, А. М. Орлеан в одній із останніх своїх публікацій зазначає, що цією формою охоплюються незаконні дії з передачі (одержання) людини. При цьому незаконність дій 3 передачі (одержання) людини, на переконання цього науковця, може бути пов'язана 3 вчиненням купівліпродажу, передачею людини в рахунок погашення боргу або в обмін на інші, крім грошей, цінності або на послуги матеріального характеру, передачею людини в оренду, її даруванням, тощо [29, с. 30]. Видається, що таке трактування «торгівлі людиною» безпідставно розширює зміст цієї форми досліджуваного злочину. Підстав для віднесення до власне торгівлі людиною, скажімо, передачі людини в оренду чи її дарування немає, оскільки це відмінні за правовою природою від купівліпродажу договори, сутність яких не відображає вживане законодавцем поняття «торгівля людиною». У зв'язку з цим варто зауважити, що відповідну позицію А. М. Орлеан зайняв після того, як вітчизняний законодавець у вересні 2018 р. із назви та диспозиції ст. 149 КК України прибрав таку форму розглядуваного діяння як «інша незаконна угода, об'єктом якої є людина». До цього ж часу вказаний дослідник підкреслював, що під торгівлею людьми як першої форми злочину, передбаченого ст. 149 КК України, слід розуміти дії з купівлі-продажу людини, що полягають у безповоротній передачі (отриманні) людини за грошову ви- нагороду, тоді як дії, спрямовані на вчинення інших, не пов'язаних з купівлею-продажем людини, угод (зокрема, передачу людини в рахунок погашення боргу, в обмін на інші, крім грошей, цінності або послуги матеріального характеру, дарування, передачу в оренду) зараховував до «здійснення іншої незаконної угоди, об'єктом якої є людина» [18, с. 290; 19, c. 30-32]. На наше переконання, потрібно не розширювати реальний зміст поняття «торгівля людиною», а виправляти існуючу в кримінальному законі прогалину, пов'язану з відсутністю кримінально-правової заборони інших незаконних угод щодо людини [30, с. 209; 31, с. 189-190].

Аналіз судової практики засвідчує, що як торгівлю людиною найчастіше кваліфікують купівлюпродаж дитини. У цьому зв'язку варто зазначити, що у науковій літературі неодноразово пропонувалось встановити самостійну кримінальну відповідальність за торгівлю неповнолітніми $[25$, с. $104 ; 32$, с. $17 ; 33$, c. $14 ; 34$, c. $3-4,11,28 ; 35$, c. $8,9,17$, $19 ; 36$, с. $9,10-11,64-69 ; 37$, c. $60 ; 38$, c. $455-456 ; 39$, с. $137-142]$. Зауважимо, що таким шляхом пішло немало законодавців (зокрема, Албанії, Bipменії, Грузії, Казахстану, Литви, Молдови, Німеччини, Хорватії). Поняття торгівлі дітьми відоме й міжнародному праву. Так, у ст. 2 Факультативного протоколу до Конвенції про права дитини щодо торгівлі дітьми, дитячої проституції і дитячої порнографії торгівля дітьми визначається як будь-який акт або угода, внаслідок яких дитина передається будьякою особою або будь-якою групою осіб іншій особі або групі осіб за винагороду або інше відшкодування [40]. Відповідні дії вважаються торгі- 
влею дітьми незалежно від наявності мети їх експлуатації. На наш погляд, виокремлення торгівлі дітьми в самостійну статтю КК України позбавлене сенсу, адже відповідні діяння цілком можуть бути кваліфіковані за ст. 149 КК України. Аргументи деяких науковців про те, що торгівля дітьми, на відміну від торгівлі дорослими людьми, посягає передусім на психічне, фізичне, моральне здоров'я та нормальний розвиток дитини, а тому відповідна кримінальноправова заборона має знайти своє місце в розділі про злочини проти сім'ї та неповнолітніх [32, с. $17 ; 35$, c. $17 ; 36$, с. $67 ; 39$, с. $140 ; 41$, с. 15$]$, не видаються достатньо переконливими. По-перше, розділу, у якому було б сконцентровано діяння проти сім'ї та неповнолітніх, вітчизняний законодавець не виокремлює. По-друге, не заперечуючи того, що торгівля дітьми посягає на нормальний розвиток та інтереси дитини, вважаємо, що передовсім вказане діяння посягає на її особисту свободу та гідність. Потретє, виокремлення торгівлі дітьми в самостійний склад призведе до надмірної казуальності вітчизняного кримінального закону [30, с. $210 ; 31$, c. 190-191].

Звертає на себе увагу той факт, що, розкриваючи зміст торгівлі людиною як форми розглядуваного злочину, окремі дослідники вказують, що потерпіла від цього діяння особа передається у незаконну власність покупцеві чи іншій особі [14, с. $282 ; 24$, с. $23 ; 25$, с. $99 ; 42$, с. 245$]$. Погодитись 3 такими твердженнями не можемо. На наш погляд, має рацію В. А. Козак, який підкреслює, що власність як юридична категорія передбачає наявність у певного суб'єкта наданих законом повноважень 3 во- лодіння, користування та розпорядження майном, а тому «незаконною» власність за жодних обставин бути не може [3, с. 54]. Крім того, не можна забувати, що людина $\epsilon$ суб'єктом, а не об'єктом матеріального світу, а тому у власність апріорі переходити не може.

Таким чином, використовуючи напрацювання інших дослідників (зокрема, В.А. Козака [3, с. 59] та А. М. Орлеана [18, с. 290]), торгівлю людиною як форму розглядуваного злочину можемо визначити як дії 3 купівлі-продажу людини, що полягають у безповоротній (тобто назавжди) передачі (отриманні) винним людини за грошову винагороду [30, с. $210 ; 31$, с. 191].

Дискусійним $\epsilon$ питання про момент закінчення розглядуваного злочину у формі торгівлі людиною. Так, на думку В.І.Борисова та В. А. Козака, діяння у цій формі потрібно вважати закінченим з моменту одержання покупцем людини або 3 моменту встановлення щодо потерпілої особи фактичного володіння 3 боку особи, якій він був переданий $[23$, с. $156 ; 27$, с. $113 ; 43$, с. $614 ; 44$, c. 19]. В. О. Іващенко вважає, що закінченим це діяння слід вважати 3 моменту заволодіння людиною. На їі переконання, сам факт продажу людини знаходиться за межами об'єктивної сторони складу злочину і характеризує лише його суб'єктивну спрямованість [20, с. 25; 45, с. 9]. На думку Я. Г. Лизогуба, закінченим таке діяння потрібно вважати з моменту досягнення домовленості між покупцем i продавцем про купівлюпродаж потерпілої особи й отримання у зв'язку з цим відповідної суми грошей [13, с. 117]. А. М. Орлеан вважає, що купівлю-продаж людини слід 
вважати закінченою з моменту безповоротної передачі людини та отримання (або досягнення домовленості на отримання) хоча б частини грошової винагороди [6, с. 102]. Таким чином, одні дослідники вважають, що для визнання цього діяння закінченим необхідно встановити факт одержання покупцем людини або фактичного заволодіння нею, другі вважають, що достатньо констатувати факт досягнення домовленості про купівлю-продаж людини та одержання продавцем грошей, треті ж переконані, що купівляпродаж людини як закінчений злочин означає безповоротну передачу людини покупцеві, який, своєю чергою, отримує за «живий товар» грошову винагороду. На наш погляд, більш переконливою $є$ точка зору тих науковців, які момент закінчення торгівлі людьми у розглядуваній формі пов'язують 3 передачею людини іншій особі, яка сплатила за неї певну суму грошей $[30$, с. $211 ; 31$, c. 191].

На думку М. І. Хавронюка, навіть попри те, що відповідна угода вчиняється щодо людини, що перетворює ії юридичну сутність із законної на незаконну, зовнішня правова оболонка цієї угоди залишається незмінною $[15$, с. 443$]$. Порівнюючи цивільно-правове поняття купівліпродажу і купівлю-продаж людини як злочинне діяння, насамперед необхідно зазначити, що і договір купівлі-продажу і купівля-продаж людини $\epsilon$ вольовими актами. Вступаючи в цивільно-правові відносини, їх суб'єкти реалізують своє бажання (або внутрішню волю) породити певні правові наслідки. Способи вираження волі в цивільному праві зазвичай об’єднують в три групи - пряме волевиявлення, виражене в усній чи письмовій (а нині і в електронній) формі, опосередковане волевиявлення, коли воля виражається у відповідних конклюдентних діях, i вираження волі шляхом мовчання. В кримінальному ж праві психологічні, вольові моменти злочинної діяльності відносять до суб'єктивної сторони злочину, що характеризує внутрішнє ставлення суб'єкта злочину до вчиненого ним суспільно небезпечного діяння. Суб'єктивна сторона злочину, передбаченого ст. 149 КК України, характеризується прямим умислом і спеціальною метою - експлуатацією людини. Зовнішнім вираженням волі в даному випадку $\epsilon$ об'єктивна сторона розглядуваного злочину [46, с. 106]. Купівля-продаж в цивільному праві характеризується рядом відмінностей від купівліпродажу як ознаки об'єктивної сторони торгівлі людьми: 1) якщо в цивільному праві договір купівліпродажу є правомірною дією, то купівля-продаж людини визнається злочином; 2) предметом договору купівлі-продажу в цивільному праві може бути товар, майнові права та право вимоги (ст.656 Цивільного кодексу України). Людина ж легально не може бути предметом купівліпродажу або перебувати у чиійсь власності; 3) договір купівліпродажу в цивільному праві породжує певні права та обов'язки сторін, котрі, у разі порушення однією із сторін договору його умов, підлягають захисту з боку держави. Сторона, чиї права та інтереси були порушені, має право звертатися до суду з позовною заявою (про відшкодування завданих їй збитків, про заміну товару тощо). Вчинення купівлі-продажу людини тягне за собою кримінальну 
відповідальність [див. дет.: 25, с. 9799; 46, с. 106-108].

Необхідно звернути увагу на те, що у ст. 149 КК України терміном «торгівля людьми» законодавець позначає не тільки власне торгівлю людиною - тобто вчинення щодо неї договору купівлі-продажу, а й усі інші передбачені в ній форми розглядуваного посягання, на що вказує назва зазначеної статті. Навряд чи коректно у диспозиції ч. 1 ст. 149 для позначення купівлі-продажу людини використовувати термін, яким законодавець позначає й всі інші форми досліджуваного злочину. За такого підходу можна дійти висновку, що назва ст. 149 КК України лише частково відображає їі зміст, оскільки передбачає відповідальність не тільки за торгівлю людиною, а й за вербування, переміщення, переховування, передачу або одержання людини. У зв'язку з цим вважаємо, що у диспозиції зазначеної норми одну з форм торгівлі людьми також називати торгівлею людиною не виправдано. Оскільки під власне торгівлею людиною прийнято розуміти її купівлю-продаж, вказану форму розглядуваного злочину варто було б назвати купівлею-продажем людини, а не торгівлею людиною. За такого підходу вдасться уникнути двозначності, пов'язаної 3 розумінням сутності торгівлі людьми. Зазначимо, що до подібного висновку раніше дійшли й інші дослідники $[6$, с. 102,177 ; 18 , с. $379 ; 47$, с. $117 ; 48$, с. $122 ; 49$, c. 16].
Однією з форм торгівлі людьми донедавна визнавалась «інша незаконна угода, об'єктом якої є людина», однак Законом України від 6 вересня 2018 р. Верховна Рада України вилучила її зі ст. 149 КК України ${ }^{1 .}$ Такий крок законодавцем пояснювався необхідністю приведення вказаної статті у відповідність до міжнародних стандартів [51; див. також: 52]. Разом 3 тим має рацію А.М. Орлеан, який підкреслює, що міжнародно-правові акти не забороняють криміналізувати ширше коло суспільно небезпечних діянь, в тому числі й «іншу незаконну угоду щодо людини». Міжнародні стандарти визначають лише мінімальне коло діянь, що їх слід криміналізувати, й жодною мірою не обмежують можливості кожної держави розширити зміст відповідної кримінальноправової заборони [53, с. 57]. Оскільки під власне торгівлею людиною слід розуміти лише здійснення щодо неї договору купівлі-продажу, а також зважаючи на той факт, що кримінальна відповідальність за інші форми розглядуваного діяння настає тільки тоді, якщо вони вчинені з метою експлуатації людини, можна стверджувати, що згадане рішення законодавця призвело до наявності прогалини, яка у ряді випадків унеможливлює кваліфікацію за ст. 149 КК України. До подібного висновку дійшли й деякі інші вітчизняні дослідники [54, с. 144].

Під «здійсненням іншої незаконної угоди, об'єктом якої є людина» у юридичній літературі здебіль-

1 Зауважимо, що ще на етапі розгляду відповідного законопроекту Головне юридичне управління слушно вказувало, що «виключення із об'єктивної сторони статті 149 КК України такої форми злочинної діяльності як “здійснення іншої незаконної угоди, об”єктом якої є людина" по суті означає декриміналізацію відповідного діяння» [50]. 
шого розуміли інші, окрім купівліпродажу, випадки передачі людини ${ }^{1}$ однією особою та іï одержання іншою особою на підставі незаконної угоди $[11$, с. $81 ; 17$, с. $310 ; 23$, с. 156 ; 42, с. 246]. До таких угод відносили, зокрема, дарування, міну, надання у безоплатне користування, передачу в рахунок погашення боргу тощо [15, c. $444 ; 17$, с. $310 ; 23$, с. $156 ; 42$, с. 246 ; 53, c. 57]. При цьому слушно зазначалося, що передача людини у разі здійснення іншої незаконної угоди щодо неї може бути як безповоротною, так $\mathrm{i}$ на певний строк [23, с. 156]. Зауважимо, що у правозастосовній практиці ця форма торгівлі людьми траплялася доволі рідко. На цей факт звертає увагу також А.М.Орлеан, на думку якого вилучення «здійснення іншої незаконної угоди, об'єктом якої є людина» 3 опису об'єктивної сторони злочину, відповідальність за який передбачена у ст.149 КК України, користі не принесе, однак й великої шкоди не завдасть [53, с. 57-58]. Водночас вважаємо, що кримінальний закон має забезпечувати всебічну охорону прав і свобод людини та громадянина від злочинних посягань, тоді як вказані зміни до ст. 149 КК України фактично протирічать цьому завданню. На наше переконання, дану форму аналізованого злочину необхідно повернути до статті про кримінальну відповідальність за торгівлю людьми [30, с. 213; 31, с. 193].

Разом $з$ тим законодавче формулювання цієї форми торгівлі людьми навряд чи можна було визнати задовільним. Так, А. М. Орлеан слушно звертає увагу на некоректність визнання людини об'єктом угоди $[18$, с. 290-291]. Дійсно, людина $\epsilon$ суб'єктом, а не об'єктом матеріального світу, а тому об'єктом угоди бути не може. Виходячи із положень цивільного законодавства, А. М. Орлеан вважає, що людина виступає предметом угоди [18, с. 291]. Видається, оптимальним варіантом формулювання цієї форми розглядуваного злочину був той, який мав місце в назві попередньої редакції ст. 149 - «... угода щодо людини». До такого ж висновку дійшла О. П. Горпинюк [12, с. 265].

Навряд чи коректним було також уточнення законодавця про незаконність укладеної щодо людини угоди, адже будь-яка угода щодо людини апріорі не може бути законною [див. також: 42, с. 246]. У зв'язку 3 цим варто погодитись з Г. З. Яремко, на думку якої відповідна бланкетна вказівка у ч. 1 ст. 149 КК України не мала змістовного навантаження [55, c. 217].

1 Іншу точку зору обстоює Я. Г. Лизогуб, який зазначає: «3 огляду на те, що угода купівлі-продажу потерпілого передбачена першою формою об'єктивної сторони злочину, а інші угоди з приводу передачі та одержання людини за логікою ст. 149 КК - шостою і сьомою формами відповідно, під здійсненням іншої незаконної угоди, об'єктом якої є людина, пропонується розуміти дії, які не мають на меті передачу людини; щоправда, людина тут є об'єктом використання» [13, с. 115]. Видається, що для зазначеного висновку не було достатніх підстав. Справа в тому, що передача та одержання людини як окремі форми торгівлі людьми передбачають обов'язкову мету їх вчинення - мету експлуатації, тоді як при передачі та одержанні людини у разі здійснення щодо неї іншої незаконної угоди така мета законодавцем не вимагалась. На практиці чи не найпоширенішим прикладом здійснення іншої незаконної угоди, об’єктом якої є людина, були випадки безоплатної передачі матір'ю своєї дитини іншій особі для подальшого її усиновлення. 
На думку Ю. С. Нагачевської, замість цивільно-правового терміна «незаконна угода» у ч. 1 ст. 149 КК України доцільніше було вживати термін «незаконні дії», що «вживається в кримінальному праві для позначення злочинного вчинку людини» $[42$, с. 246]. 3 такою пропозицією погодитись не можемо, оскільки термін «дії» не $\epsilon$ еквівалентним терміну «угода». Вважаємо, що термін «незаконні дії щодо людини» $є$ надто широким за змістом i, серед іншого, не може не породити нову проблему, пов'язану із співвідношенням цієї, пропонованої Ю.С. Нагачевською, форми торгівлі людьми та такими формами досліджуваного злочину як вербування, переміщення, переховування, передача або одержання людини, які за своєю природою, зрозуміло, також є діями (у даному випадку незаконними) [30, с. 213-214].

У розглядуваному контексті зауважимо, що в чинному Цивільному кодексі України використовується термін «правочин», а не «угода». Правочином у ньому визнається дія особи, спрямована на набуття, зміну або припинення цивільних прав та обов'язків (ч. 1 ст. 202). Вітчизняні цивілісти підкреслюють, що хоча у цивільному законодавстві правочин визначається як «дія», це слово не можна сприймати у відриві від подальшого тексту, наведеного у ч. 1 ст. 202 Цивільного кодексу України, а саме від «спрямована на ...»; сутність правочину не у фактичних діях, а у спрямованості на набуття, зміну або припинення цивільних прав та обов'язків. Інші науковці, визначаючи поняття правочину, акцентують увагу на тому, що ним є дозволена правомірна дія, яка спрямована на досягнення позитивного правового результату, що визнається й охороняється державою, підкреслюють, що правочин - дія завжди правомірна, що відрізняє ії від таких юридичних фактів, як правопорушення [56, c. 84]. Зазначимо також, що у ст. 203 Цивільного кодексу України, яка встановлює загальні вимоги, додержання яких $\epsilon$ необхідним для чинності правочину, вказано, що «зміст правочину не може суперечити цьому Кодексу, іншим актам цивільного законодавства, а також інтересам держави і суспільства, його моральним засадам» [28]. Зважаючи на викладене, вважаємо, що використовувати цей термін у розглядуваній статті КК України некоректно, оскільки будь-які угоди щодо людини правочином апріорі визнаватися не можуть. Натомість, як видається, термін «угода» $\epsilon$ більш нейтральним й таким, що може використовуватись у наведеному вище контексті [30, c. 214].

Сутність вербування людини як форми торгівлі людьми у кримінально-правовій літературі особливих дискусій не викликає. Визначення, що їх наводять дослідники, загалом відповідають семантичному значенню слова «вербувати», яке означає «наймати, набирати людей на роботу», «залучати до якоїсь діяльності» [57, с. 121]. Так, на думку В. І. Борисова i В. А. Козака, вербування людини - це різноманітні дії, пов'язані із схилянням особи працювати чи надавати послуги на певних умовах, як правило, за матеріальну винагороду. До таких дій, на переконання вказаних науковців, необхідно відносити психічний вплив на людину у формі запрошення, умовляння чи переконання для подальшого іiі набору, а також сам набір потерпілої 
особи працювати чи надавати послуги за наймом $[23$, с. $157 ; 27$, с. 113 ; 43 , c. $615 ; 44, \quad$ c. $20 ; \quad 58, \quad$ c. 17$]$. I.А. Вартилецька, своєю чергою, вважає, що вербування людини - це запрошення, набір або залучення шляхом домовленості осіб для їх участі у будь-яких видах діяльності [21, c. $342 ; 59$, c. 101$]$.

Сутність вербування пояснюється також в кримінальному законодавстві деяких держав. Так, у примітці до ст. 171 КК Киргизстану зазначено, що під вербуванням слід розуміти діяльність фізичних чи юридичних осіб з пошуку, відбору та найму людей за матеріальну винагороду для виконання будь-яких робіт, надання послуг в інтересах наймача або інших осіб.

На відміну від більшості дослідників, окремі науковці вказують на те, що вербування людини може відбуватися й на недобровільній основі. Так, на переконання А. М. Орлеана, під вербуванням слід розуміти вчинення дій, спрямованих на досягнення 3 людиною добровільної (наприклад, шляхом запрошування або умовляння) або вимушеної (наприклад, шляхом шантажу або погрози застосування насильства) домовленості на їі подальшу експлуатацію або на переміщення, переховування, передачу іншій особі [18, с. 291]. Дана позиція, 3 одного боку, відповідає положенням кримінального закону, який у ч. 1 ст. 149 вказує, що такі форми торгівлі людьми як вербування, переміщення, переховування, передача або одержання людини вчиняються, зокрема, 3 використанням примусу або шантажу. 3 іншого ж, як засвідчує аналіз судової практики, в об'єктивній дійсності вербування фактично завжди здійснюється шля- хом запрошування, переконування або умовляння (при цьому вербувальник, як правило, використовує обман або ж уразливий стан потерпілої особи), завдяки чому вдається схилити особу працювати чи надавати послуги на певних умовах [30, c. 214-215].

Навряд чи можна погодитись 3 авторами, які трактують вербування як «дії, спрямовані на одержання згоди людини на володіння або розпорядження нею іншою особою» [16, c. 385]. Будучи завербованою, потерпіла від розглядуваного злочину особа дає згоду не на володіння чи розпорядження нею, а на те, аби працювати чи надавати послуги на певних умовах.

В юридичній літературі висловлювалася точка зору, що під вербуванням людини слід розуміти «досягнення домовленості шляхом безпосереднього наймання, тобто запрошування і набору добровольців нібито для участі у певній діяльності» $[15$, с. 444]. Відповідно, моментом закінчення цього злочину у вказаній формі запропоновано вважати момент, коли потерпіла особа була завербована [15, с. 443]. На наш погляд, варто погодитись з B.I. Борисовим та В.А. Козаком, які вказують, що за такого підходу увага акцентується не стільки на самому процесі вербування, у якому полягає сутність цієї дії, скільки на його результаті (досягненні згоди між вербувальником та потерпілим) [23, с. 157]. У зв'язку з цим більш переконливою видається позиція зазначених науковців, які вважають, що момент закінчення аналізованого злочину у формі вербування людини слід визнавати закінченим 3 моменту самого вербування, тобто 3 моменту вчинення 
дій, пов'язаних із набором потерпілої особи працювати чи надавати послуги на певних умовах [23, с. $158 ; 43$, c. $615 ; 58$, c. 17$]$.

Розуміння переміщення людини як форми торгівлі людьми у спеціальній літературі також не викликає особливих труднощів. Так, приміром, М. І. Хавронюк слушно вказує, що під переміщенням людини слід розуміти зміну місця ï перебування шляхом перевезення та іншого переміщення їі як через державний кордон України, так і в межах території України $[15$, с. 444$]$. При цьому варто погодитись 3 А. М. Орлеаном, який позитивним нововведенням чинної редакції ст. 149 КК України вважає те, що переміщення людини визнано законодавцем альтернативною формою розглядуваного діяння. Нагадаємо: згідно 3 попередньою редакцією ст. 149 встановлювалась відповідальність за такі дії, як «продаж, інша оплатна передача людини, а так само здійснення стосовно неї будь-якої іншої незаконної угоди, пов'язаної із законним чи незаконним переміщенням за ії згодою або без згоди через державний кордон України для подальшого продажу чи іншої передачі іншій особі (особам) з метою сексуальної експлуатації, використання в порнобізнесі, втягнення у злочинну діяльність, залучення в боргову кабалу, усиновлення (удочеріння) в комерційних цілях, використання у збройних конфліктах, експлуатації іï праці...». А. М. Орлеан слушно підкреслює, що таке формулювання диспозиції статті породжувало зайві дискусії щодо того, чи $€$ переміщення обов'язковою ознакою для всіх або лише для однієї форми торгівлі людьми [18, с. 292].
Зауважимо, що в міжнародних актах йдеться не про «переміщення», а про «перевезення» людини. На наш погляд, термін, що його використовує вітчизняний законодавець, $є$ оптимальнішим, оскільки винний може не тільки перевозити потерпілу особу з використанням транспортного засобу, а й переміщати їі, скажімо, шляхом пішого супроводу [30, с. 216; 31, c. 195].

Аналіз судової практики засвідчує, що у правозастосовній практиці виникають труднощі, пов'язані 3 кваліфікацією розглядуваного злочину у разі, якщо потерпілу особу не вдалося перемістити через державний кордон України. Чи не найчастіше це стосується ситуацій, коли винного затримують в аеропорту (або ж на залізничному вокзалі) разом із потерпілою особою при спробі покинути територію України. В одних випадках суди вказували на те, що переміщення людини тут мало місце $[60 ; 61 ; 62 ; 63]$, в других - доходили протилежного висновку [64; 65; 66; 67; 68], в третіх - кваліфікували такі випадки як замах на переміщення людини [69; 70]. На наш погляд, діяння у цій формі слід вважати закінченим 3 моменту переміщення людини з одного місця до іншого, тобто той факт, що потерпілого з незалежних від винного причин не переміщено через державний кордон, не означає, що ця форма торгівлі людьми відсутня, якщо особу все ж перемістили в межах території України. У зв'язку з цим не можемо погодитись 3 колегією суддів Нікопольського міськрайонного суду Дніпропетровської області, яка, з одного боку, встановила, що Особа-1 завербувала трьох жінок 3 метою сексуальної експлуатації в Туреччині та переміс- 
тила їх на літак сполученням «Дніпропетровськ - Батумі», з іншого ж констатувала, що оскільки жінки не покинули територію України, дії Особи-1 слід кваліфікувати тільки як вербування [66].

У судовій практиці трапляються випадки, коли особа не супроводжує завербовану людину до певного місця особисто, а лише купує для неї проїзні документи, дає їй гроші на дорогу тощо, тоді як до місця призначення потерпіла особа переміщається самостійно. На думку О. О. Кислової, з якою варто погодитись, під переміщенням людини слід розуміти не лише ії фактичне транспортування, а й організаційні дії, спрямовані на здійснення переміщення [26, с. 167]. Аналогічну позицію займає й О. В. Костилєва, на переконання якої саме такий зміст вкладено у слово «transportation», що вжите в Палермському протоколі [37, c. 62]. Варто також зазначити, що Верховний Суд Республіки Казахстан 3 цього приводу надав таке роз'яснення: «Перевезення може полягати не лише в доставці переміщуваної особи у супроводі будь-кого, але й у придбанні переміщуваній особі проїзних документів до місця призначення, куди вона добирається самостійно» [71]. Переміщенням людини вчинення вказаних вище дій здебільшого визнає й вітчизняна правозастосовна практика [72; 73; 74].

Випадки, коли потерпілу особу 3 метою експлуатації незаконно переправляють через державний кордон України, мають кваліфікуватися як торгівля людьми (ст. 149 КК) та незаконне переправлення осіб через державний кордон України (ст. 332 КК). Для прикладу, Краснодонський міськрайонний суд Луганської області встановив, що Особа-1 разом із завербованими нею з метою сексуальної експлуатації трьома жінками пішки намагалися перейти державний кордон України поза пунктом пропуску на територію Російської Федерації, однак були затримані співробітниками прикордонної служби України. Суд кваліфікував вчинене Особа-1 за сукупністю злочинів, передбачених $\quad$ ч. 2 ст. 149 та ч. 1 ст. 332 КК України [75].

Під переховуванням людини прийнято розуміти розміщення людини у певному приміщенні, у транспортному засобі, у певній місцевості тощо, забезпечення їі підробленими документами, вчинення щодо неї пластичної операції зі зміни зовнішності тощо $[15$, с. $444 ; 21$, с. $343 ; 23$, c. $158 ; 25$, с. $101 ; 27$, с. $114 ; 59$, с. 102 ; 76, с. 154]. Йдеться, таким чином, про дії суб'єкта злочину, спрямовані на те, аби унеможливити або ж ускладнити встановлення третіми особами місця перебування потерпілої особи $[13$, с. $116 ; 14$, с. $282 ; 16$, с. $385 ; 17$, c. $311 ; 23$, с. $158 ; 27$, с. $114 ; 77$, с. 10$]$. Слід зауважити, що у правозастосовній практиці ця форма торгівлі людьми трапляється порівняно рідко. Для прикладу, Луцький міськрайонний суд Волинської області встановив, що учасники організованої групи переховували потерпілого, що виразилося в обмеженні фізичних контактів його з іншими особами, в тому числі з представниками правоохоронних органів, у контролі за діями та спілкуванням під час виконання роботи та у вільний час, в обмеженні свободи пересування, а також в утримуванні його в приміщенні господарської споруди [78].

Дискусійним у літературі є питання про сутність таких форм торгівлі людьми як передача або оде- 
ржання людини. Так, на думку Я. Г. Лизогуба, під передачею людини слід розуміти дії винного з приводу відчуження потерпілого, але або на певний час (передача в оренду), або назавжди, але безоплатно (дарування). Відповідно, під одержанням людини, на його думку, необхідно розуміти дії винного з приводу придбання потерпілого, але або на певний час (придбання в оренду), або назавжди, але безоплатно (як наслідок дарування) [13, с. 116]. Видається, що для вказаного висновку немає підстав. У ст. 149 КК України передбачено відповідальність за передачу або одержання людини, якщо вони вчинені одним із передбачених у цій статті способів, а також з метою експлуатації людини. Про ніяке відчуження ${ }^{1}$ людини у ній не йдеться. Вочевидь, маються на увазі ситуації, коли вербувальник чи інша особа передає потерпілого особі, яка й експлуатуватиме його, а та, своєю чергою, одержує потерпілого з цією метою. Приміром, Синельниківський міськрайонний суд Дніпропетровської області встановив, що група осіб, яка діяла за попередньою змовою, шляхом обману завербувала для заняття проституцією в Російській Федерації двох дівчат, перевезла їх до Москви, де на залізничному вокзалі передала невстановленому чоловіку. Вказаний чоловік привіз дівчат до квартири, де повідомив їм про те, що їх робота полягатиме у вступі в статевий зв'язок зі сторонніми особами за грошову винагороду [79].

I. А. Вартилецька вважає, що передача та одержання людини означають встановлення фактичного контролю над місцем її перебування, позбавлення можливості вільного пересування після здійснення купівлі-продажу або іншої незаконної угоди щодо людини [21, с. $343 ; 59$, c. 102]. По-перше, ще раз підкреслимо, що передача та одержання людини як окремі форми торгівлі людьми не мають стосунку до купівліпродажу людини або іншої незаконної угоди щодо людини ${ }^{2}$. По-друге, слід погодитись 3 А.М. Орлеаном, який слушно вказує на те, що ознаки, які наводить I. А. Вартилецька, не роз'яснюють суті таких діянь, як «передача» або «одержання» [18, c. 294]. Зворот «установлення фактичного контролю над місцем їі перебування, позбавлення можливості вільного пересування» ілюструє факт позбавлення людини свободи, а не вказує на її передачу іншій особі чи іiі одержання нею. А. М. Орлеан вважає за можливе погодитись з авторами, які передачу або одержання людини розглядають як вчинення дій, пов'язаних із переходом контролю над людиною від однієї особи до іншої [18, с. 294]. Разом з тим, на наш погляд, і таке визначення $\epsilon$ не зовсім точним, оскільки, знову ж таки, не

\footnotetext{
${ }^{1}$ Слово «відчужувати» мовознавцями тлумачиться так: «Спираючись на певний закон, відбирати в кого-небудь майно на користь держави, організації чи окремої особи» [57, с. 185].

2 Не можемо погодитись також з Д.О. Негодченко, яка вважає, що передача людини як окрема форма торгівлі людьми «передбачає вчинення дій суб'єктом злочину, які пов'язані із переданням потерпілого у фактичну власність іншій людині (покупцю) для наступного використання. Зазначені дії можуть вчинятись особою, котра виступає посередником між сторонами незаконної угоди (продавцем і покупцем)» $[17$, с. 311-312]. Цілком очевидно, що Д.О. Негодченко не розібралась із відмінностями між передачею людини як окремою формою торгівлі людьми та передачею людини у разі її купівлі-продажу.
} 
дозволяє чітко відмежувати передачу або одержання людини як окремі форми торгівлі людьми від передачі та одержання людини у разі її купівлі-продажу чи здійснення щодо неї іншої незаконної угоди. На наш погляд, відповідною розмежувальною ознакою є передусім мета експлуатації людини, що ії переслідує винний. У зв'язку з викладеним вважаємо, що передачу або одержання людини як окремі форми торгівлі людьми можна визначити як вчинення 3 метою експлуатації (а також хоча б одним із перелічених у ст.149 КК України способів) дій, пов'язаних із переходом контролю над людиною від однієї особи до іншої [30, с. $218 ; 31$, c. 197].

Передача та одержання людини, зрозуміло, тісно пов'язані між собою, адже, по суті, є двома сторонами (моментами) однієї дії (невипадково законодавець поставив між ними сполучник «або»). У той же час цілком очевидно, що один суб'єкт злочину не може одночасно вчинити і передачу, і одержання однієї людини. Передають завжди комусь, а одержують від когось. 3 огляду на це некоректним видається твердження Луцького міськрайонного суду Волинської області про те, що «організована група в складі Особа-5, Особа6, Особа-3 та Особа-7 здійснила вербування, переміщення, переховування, передачу та одержання щодо дев'яти громадян», адже, як встановив суд, зазначена організована група передавала завербованих осіб 3 метою їх експлуатації у формі примусової праці Особі-8 [78].

у розглядуваному контексті необхідно також зазначити, що у правозастосовній практиці трапляються випадки, коли у вину особі безпідставно ставляться всі форми торгівлі людьми, перераховані у диспозиції ч. 1 ст. 149 КК України, тоді як насправді мають місце лише однадві форми. У зв'язку із цим потрібно підкреслити, що вказані у даній статті форми торгівлі людьми є альтернативними, тобто для встановлення об'єктивної сторони складу злочину слід констатувати наявність хоча б однієї з них. Виходячи із зазначених міркувань Новоукраїнський районний суд Кіровоградської області дійшов слушного висновку про необхідність виключити з обвинувачення підсудним таких форм розглядуваного злочину як переховування, передача або одержання людини, залишивши лише вербування та переміщення людини $з$ метою експлуатації, вчинені з використанням обману [80].

У юридичній літературі неодноразово зверталася увага на те, що вербування, переміщення, переховування, передача або одержання людини як форми торгівлі людьми не відображають сутність поняття «торгівля» $[34$, с. 9,$21 ; 46$, с. $110 ; 81$, c. $24 ; 82$, c. $152-153 ; 83$, c. $103-104$, $118 ; 84$, c. $9-10,149-152 ; 85$, с. 102]. Так, наприклад, Г. К. Іщенко підкреслює, що в поняття торгівлі людьми не слід включати дії, що полягають у вербуванні, перевезенні чи переховуванні, оскільки вони, по суті, такою не $\epsilon$, а характеризують поведінку, яка супроводжує, передує або йде слідом за нею, і яка може бути кваліфікована як співучасть у торгівлі людьми або як окремий злочин. Щодо дій, які полягають у передачі та одержанні людини, вчинених 3 метою її експлуатації, то вони, на думку дослідниці, характеризують акт самої купівлі-продажу або іншої угоди 
щодо людини, адже продати, купити чи вчинити будь-яку іншу угоду неможливо, фактично не передавши або не одержавши предмет угоди [84, c. 9, 149-150]. Подібні аргументи наводять також А.Б. Бекмагамбетов $[81$, с. 24$]$, Б. Р. Бухорієв [86, с. $10-11$, 16], О.Г. Горбань [87, с. 24], Л. Ю. Єгорова [34, с. 9, 21], А. О. Жинкін $[46$, с. 110$]$, Д. Я. Зайдієва [88, с. 96-98], Ф. М. Кадніков [89, с. 9, 17], О. О. Кислова [85, с. 102], Ю. П. Смирнов [91, с. 9] та інші дослідники. 3 огляду на зазначені міркування Г. К. Іщенко вважає за доцільне передбачити у кримінальному законі дві статті - про відповідальність за торгівлю людьми (тобто купівлю-продаж людини) чи здійснення інших угод щодо людини, а також за сприяння торгівлі людьми чи іншим угодам щодо людини (до таких пропонується відносити вербування, перевезення чи переховування людини, вчинені 3 метою їі експлуатації) [84, с. 9-10, 151-152]. Згадані вище автори також пропонують подібні норми, з тією різницею, що до дій, які характеризують сприяння торгівлі людьми, вважають за доцільне відносити також передачу або одержання людини, вчинені 3 метою експлуатації [82, с. 153; 87, c. $24 ; 91$, с. 9].

Очевидним є те, що Г. К. Іщенко та інші вказані дослідники не беруть до уваги той факт, що міжнародноправові акти під торгівлею людьми розуміють якраз ті дії, які вони пропонують називати «сприянням торгівлі людьми». Термін «торгівля людьми», який вживається для позначення здійснюваних з метою експлуатації вербування, переміщення, переховування, передачі або одержання людини, можливо, не зовсім точно відображає фактичний зміст зазначених дій ${ }^{1}$, однак $€$ загальновизнаним у міжнародному праві та кримінальному законодавстві більшості держав світу, а тому відмова від нього навряд чи виправдана. Крім того, звертає на себе увагу той факт, що науковці недостатньо чітко диференціюють власне торгівлю людиною (тобто їі купівлю-продаж) чи іншу угоду щодо людини та ті форми торгівлі людьми, для яких вирішальне значення має наявність мети експлуатації². Вербування, переміщення та

1 Зазначимо, що в науковій літературі неодноразово пропонувалося змінити назву розглядуваної статті. Наприклад, Є.Є. Шалімов вважає за доцільне викласти її в такій редакції: «Незаконні угоди з людиною, вчинені на платній та безоплатній основі» $[92$, с. 9, 20]. 3 такою пропозицією навряд чи можна погодитись, адже законодавчим поняттям «торгівля людьми» на сьогодні охоплюється тільки одна угода - купівля-продаж, тоді як інші форми торгівлі людьми не обов'язково є угодами. Зауваження викликають також редакційні моменти пропонованої назви досліджуваної статті. Так, незрозуміло, чому угоди укладаються «з людиною» (невже потерпіла особа є контрагентом?!), а не «щодо людини»; чому угоди вчиняються на платній та (а не чи) безоплатній основі.

2 Ще одним прикладом такої плутанини може слугувати позиція О.П. Горпинюк, на думку якої ч. 1 ст. 149 КК України необхідно викласти в такій редакції: «Торгівля людьми або здійснення іншої незаконної угоди щодо людини, тобто вербування, переміщення, переховування, передача, отримання та вчинення інших дій із метою експлуатації людини» [12, c. 265]. Використання пояснювального сполучника «тобто» у пропонованій О.П. Горпинюк редакції ч. 1 ст. 149 КК України засвідчує, що вказана авторка не бачить відмінностей між купівлею-продажем людини чи іншою угодою щодо людини, відповідальність за які має наставати й у разі відсутності у винного мети експлуатації, та іншими перерахованими формами торгівлі людьми. 
переховування людини не зовсім коректно визнавати сприянням купівлі-продажу людини чи вчиненню щодо неї інших угод, адже зміст останніх, як зазначалося вище, має свої характерні особливості. Аналіз емпіричної бази, приміром, засвідчує, що купівля-продаж людини рідко супроводжується їі попереднім вербуванням, адже, нагадаємо, купують і продають здебільшого дітей. Що стосується передачі та одержання людини, місце яких у торгівлі людьми дезорієнтує багатьох науковців, то мусимо ще раз наголосити на необхідності відмежування передачі або одержання людини як окремих форм торгівлі людьми від передачі та одержання людини, що мають місце у разі їі купівлі-продажу чи здійснення щодо неї іншої незаконної угоди.

На переконання А. С. Політової, «під торгівлею людьми слід розуміти дії, спрямовані на обмеження свободи людини шляхом її продажу, вчинення іншої незаконної угоди щодо неї, пов'язаної з незаконним заволодінням чи передачею 3 метою експлуатації на території України чи за іï межами» $[8$, с. 312; 77, с. 9]. Не вдаючись у детальний аналіз інших дискусійних моментів, зазначимо, що таке розуміння торгівлі людьми $\epsilon$ неприйнятним хоча б з таких причин: по-перше, торгівлею людьми не визнаються ті дії, які не завжди $\epsilon$ угодами, однак визнаються торгівлею людьми за міжнародним правом, по-друге, оскільки А. С. Політова вказує на обов'язкову мету експлуатації, 3 якою вчиняється продаж людини чи вчинення іншої угоди щодо неї, це означає, що, для прикладу, випадки купівлі-продажу дитини без мети подальшої її експлуатації (приміром, для усиновлення) не мають визнава- тись кримінально караними, 3 чим погодитись не можемо [30, с. 221].

3 диспозиції ч. 1 ст. 149 КК України випливає, що обов'язковою ознакою вчинення вербування, переміщення, переховування, передачі або одержання людини є спосіб злочинного діяння - використання примусу, викрадення, обману, шантажу, матеріальної чи іншої залежності потерпілого, його уразливого стану або підкупу третьої особи, яка контролює потерпілого, для отримання згоди на його експлуатацію. Виняток становлять випадки, коли торгівля людьми у вказаних формах вчиняється щодо малолітнього чи неповнолітнього (ч. 3 примітки до ст. 149). При цьому необхідно зазначити, що до 6 вересня 2018 р. законодавець передбачав лише три альтернативні способи вчинення цього злочину: 1) з використанням обману; 2) $з$ використанням шантажу; 3) 3 використанням уразливого стану особи. Використання матеріальної чи іншої залежності потерпілого до вказаного часу визнавалось кваліфікуючою ознакою даного злочину. Аналіз судової практики засвідчив, що такий підхід не викликав особливих труднощів у правозастосуванні і загалом виправдав себе. Зауважимо, що найчастіше способом вчинення торгівлі людьми визнається використання уразливого стану потерпілої особи, дещо рідше має місце використання обману (при цьому зазвичай ці способи поєднуються). Що стосується використання шантажу, то цей спосіб впливу на особу фіксується вкрай рідко.

Розглянемо передбачені кримінальним законом способи вчинення торгівлі людьми у перерахованих вище її формах. 
У Великому тлумачному словнику сучасної української мови обман визначається як «неправдиві слова, вчинки, дії і т. ін. // Невідповідність істині; те, чого немає насправді; брехня» [57, с. 810]. В. І. Борисов та В.А. Козак вважають, що під обманом слід розуміти повідомлення неправдивих відомостей (активний обман) або замовчування певних відомостей, які повинні бути повідомлені винним (пасивний обман), у результаті чого потерпілий вводиться в оману $[23$, с. $159 ; 27$, с. $114 ; 43$, с. $616 ; 44$, с. $20 ; 58$, с. 18$]$. Аналогічною є точка зору М. І. Панова [93, c. 40]. На думку С. Ю. Романова, обман полягає у введенні іншої особи в оману або ж підтриманні вже наявної у неї помилки шляхом передачі інформації, що не відповідає дійсності або замовчування про факти, речі, явища і т.ін. 3 метою схилити цю особу до певної поведінки $[94$, с. 3]. 3 точки зору Р. Л. Максимовича, під обманом слід розуміти безпосереднє чи опосередковане введення потерпілої чи іншої особи в оману шляхом повідомлення неправдивих відомостей чи замовчування про відомості, повідомлення про які було обов'язковим з метою вчинення злочину $[95$, с. 157$]$. Таким чином, при вчиненні розглядуваного злочину обман полягає у повідомленні особі неправдивих відомостей чи у замовчуванні відомостей, повідомлення про які могло б вплинути на ï усвідомлений вибір. Аналіз емпіричної бази засвідчує, що на практиці здебільшого має місце повідомлення винним неправдивої інформації про сферу діяльності, якою особа займатиметься (приміром, замість обіцяної роботи офіціанткою жінці доводиться займатися проституцією), або ж приховування правди стосовно ключових умов відповідної діяльності (наприклад, щодо можливості у будь-який час повернутися додому, стосовно умов проживання та суми заробітку). Прикладом торгівлі людьми, вчиненої з використанням обману, може слугувати кримінальне провадження, розглянуте Синельниківським міськрайонним судом Дніпропетровської області. Суд встановив, що Особа-6 запропонував Особі-8 та Особі-3 роботу зі збору фруктів у м. Лозова Харківської області, однак, коли ті дали свою згоду, переконав їх у вигідності їхати на роботу не в Лозову, а до Москви, де, продаючи фрукти на ринку, заробити можна набагато більше. Після прибуття до Москви дівчат передали невстановленій особі, котра повідомила, що насправді їх робота полягатиме у наданні інтимних послуг чоловікам за грошову винагороду [79].

У юридичній літературі висловлювалася думка про доцільність виокремлення такого способу вчинення розглядуваного діяння, як зловживання довірою $[18$, с. $161-$ 163]. Зазначена точка зору аргументується тим, що зловживання довірою $є$ самостійною формою впливу на особу, який не охоплюється обманом. Г. М. Анісімов 3 цього приводу зазначає, що підставою розмежування зловживання довірою й обману служать об'єктивні та суб'єктивні ознаки. При обмані потерпілий вводиться в оману тим, хто його обманює, або ж омана підтримується ним у свідомості обманюваного. Натомість при зловживанні довірою довіритель не вводиться в оману, він надає повноваження, не оманюючись щодо цілей використання останніх, їх обсягу, дій повірника тощо. Повір- 
ник (винний) із суб'єктивної сторони приймає надані йому довірителем повноваження для належного їх використання. I лише після цього в повірника виникає умисел, спрямований на вчинення злочину шляхом використання наданих повноважень, і він його скоює шляхом вчинення діяння всупереч інтересам та волі довірителя [96, с. 10]. За своєю сутністю зловживання довірою становить «зраду прийнятого обов'язку», порушення морального обов'язку бути вірним своєму слову, юридичного обов'язку щодо виконання зобов'язання [97, с. 21]. Таким чином, зловживання довірою хоч i тісно пов'язане з обманом, однак не охоплюється ним. 3 огляду на це доцільним вважаємо доповнити перелік способів вчинення торгівлі людьми у перерахованих вище їі формах таким, як зловживання довірою. На зазначений спосіб вчинення даного злочину вказується, зокрема, в ч. 1 ст. 181 КК Білорусі, ч. 1 ст. 130-1 КК Таджикистану, ч. 1 ст. 129-1 КК Туркменістану, ч. 1 ст. 444 КК Чорногорії.

Доктринальне тлумачення поняття «шантаж» також не викликає особливих труднощів. Так, B. І. Борисов та В.А. Козак зазначають, що шантаж - це психічне насильство, яке полягає у погрозі розголошення відомостей, які потерпілий чи його близькі бажають зберегти в таємниці $[23$, с. $159 ; 27$, с. $114 ; 43$, c. $616 ; 44$, с. $21 ; 58$, с. 18$]$. Аналогічне визначення наводить А. М. Орлеан $[29$, с. 33]. 3 точки зору 3. А. Тростюк (Загиней), шантаж - це реальна погроза розголошення відомостей, які потерпілий або його близькі особи бажають зберегти у таємниці, з метою примушування потерпілого до вчинення певних дій [98, с. 464; 99 , c. 169].

Під відомостями, які потерпілий бажає зберегти в таємниці, I. В. Самощенко пропонує розуміти будь-які факти з минулого або сьогоденного життя потерпілого чи його близьких родичів (навіть вже померлих), розголошення яких може спричинити шкоду їхній честі та гідності. Такі відомості можуть стосуватися як поведінки самого потерпілого чи його родичів, так і інших життєвих обставин, до яких хтось із них був причетний. Розголошені відомості можуть бути такими, що ганьблять потерпілого, а можуть і не мати такої ознаки. 3 огляду на це погроза розголосити відомості, які потерпілий бажає зберегти в таємниці, $\epsilon$ дещо ширшою, ніж погроза розголосити відомості, що ганьблять потерпілого [100, с. $4 ; 101$, с. 104]. Варто також погодитись 3 дослідниками, які підкреслюють, що невід'ємною характеристикою шантажу $\epsilon$ той факт, що він передбачає конкретну вимогу винного. Основною метою шантажу є прагнення винного домогтися від потерпілого вигідної для себе поведінки [102, с. 164]. Розрахунок шантажиста полягає в тому, що наслідки для особи, яку шантажують, $\epsilon$ більш тяжкими і несприятливими, ніж виконання його вимог, і що ця особа погодиться з їх виконанням як із меншим злом [103, с. 107].

Прикладом торгівлі людьми, вчиненої з використанням шантажу, може слугувати кримінальне провадження, розглянуте Алчевським міським судом Луганської області. Суд встановив, що після того, як учасники організованої групи провели фотосесію та розмістили фотографії Особи-11 в мережі Інтернет з пропо- 
зицією надання сексуальних послуг, їй пригрозили, що у разі, якщо вона відмовиться від надання платних сексуальних послуг, вони розклеять ці фото за місцем іï проживання [104].

Необхідно також зазначити, що в судовій практиці трапляються помилки, пов'язані із встановленням наявності шантажу як способу вербування, переміщення, переховування, передачі або одержання людини. Так, виходячи із викладеного вище, не можемо погодитись 3 висновком Бородянського районного суду Київської області, який як шантаж розцінив дії співучасників, котрі змусили потерпілих написати розписки про те, що за страйк або будь-який інший інцидент вони мають сплатити 10 тисяч доларів США, тим самим поставивши останніх у залежне становище [105]. Очевидно, що в даному та інших подібних випадках суд виходив 3 ширшого (буденного) трактування поняття «шантаж» - як погрози негативними наслідками у разі невиконання вимог. У зв'язку з цим слушною видається пропозиція 3. А. Тростюк (Загиней) закріпити визначення шантажу в «термінологічному розділі» КК України [98, с. 464; 99 , с. 169].

Вважаємо за доцільне детальніше зупинитися на з'ясуванні сутності уразливого стану особи. У ч. 2 примітки до ст. 149 КК України вказано, що «у статтях 149 та 303 цього Кодексу під уразливим станом особи слід розуміти зумовлений фізичними чи психічними властивостями або зовнішніми обставинами стан особи, який позбавляє або обмежує їі здатність усвідомлювати свої дії (бездіяльність) або керувати ними, приймати за своєю волею самостійні рішен- ня, чинити опір насильницьким чи іншим незаконним діям, збіг тяжких особистих, сімейних або інших обставин».

Виходячи із наведеного законодавчого визначення, А. М. Орлеан зазначає, що уразливий стан особи може зумовлюватись фізіологічними (фізичними чи психічними) властивостями або наявною соціальною ситуацією. 3 огляду на це науковець розрізняє фізіологічний та соціальний уразливий стан. Фізіологічний уразливий стан проявляється у відсутності здатності або в обмеженій здатності особи усвідомлювати свої дії (бездіяльність) або керувати ними, приймати за своєю волею самостійні рішення, чинити опір насильницьким чи іншим незаконним діям. Він може бути пов'язаний з віковою незрілістю дитини, психічними властивостями людини (психічна хвороба, тимчасовий розлад психічної діяльності, наявність фрустрації, стресу, шоку, фізіологічного афекту чи інших психологічних станів людини), фізичними властивостями людини (фізична хвороба або фізичні вади), штучним зовнішнім блокуванням природних психічних чи фізичних можливостей людини за допомогою медичних препаратів, наркотичних речовин тощо [18, с. $143 ; 106$, с. 128$]$. Аналіз емпіричної бази засвідчує, що фізіологічний уразливий стан найчастіше зумовлений недосягненням особою повноліття (віковою незрілістю). Прикладом використання фізіологічного уразливого стану, в якому перебувала повнолітня особа, може слугувати провадження, що його розглянув Глухівський міськрайонний суд Сумської області. Суд вказав, що відповідно до висновку судово-психологічної експертизи 
потерпіла Особа-8, яку завербували 3 метою сексуальної експлуатації в Росії, мала психічний інфантилізм, який характеризується незрілістю емоційно-вольової сфери, проявами рис дитячості, схильністю до фантазування, нездатністю ставити перед собою реальні цілі та об'єктивно оцінювати ситуацію [107].

На думку А. М. Орлеана, соціальний уразливий стан пов'язаний із сукупністю тяжких особистих, сімейних або інших обставин. Зазвичай він характеризується наявністю скрутної життєвої ситуації: втратою постійного джерела доходу та необхідністю утримувати неповнолітніх i непрацездатних осіб, наявністю великого боргу, необхідністю терміново зібрати кошти для лікування близької людини тощо [18, с. $147 ; 106$, c. 130]. «Соціальний уразливий стан може спонукати людину діяти в спосіб, що суперечить її внутрішнім цінностям та інтересам без будь-яких погроз чи обману. Перебуваючи в уразливому стані, вона може погоджуватись на вкрай невигідні та кабальні пропозиції, достатнім для чого буде лише незначне підштовхування або просте вмовляння. Саме соціальний уразливий стан може змушувати людину саму виступити ініціатором власної експлуатації» $[18$, c. $150 ; 106$, c. 131].

Аналіз емпіричної бази засвідчує, що соціальний уразливий стан становить левову частку усіх випадків використання уразливого стану особи як способу вчинення торгівлі людьми. Характерним прикладом використання соціального уразливого стану може слугувати кримінальне провадження, розглянуте Ковпаківським районним судом м. Суми. Суд встановив, що уразливий стан потерпілої Особа-3, яку завербували 3 метою сексуальної експлуатації в Туреччині, був зумовлений тим, що вона самостійно утримувала малолітню дитину, її покинув чоловік, який поставив ії у скрутне матеріальне становище, оскільки виніс з дому всі речі і залишив без засобів для існування. Допомогу від держави Особа-3 не отримувала, позаяк чоловік ухилявся від розірвання шлюбу. Дитина часто хворіла, на лікування потрібно було витрачати значні кошти. У зв'язку з цим вона вимушена була взяти багато кредитів [108].

Іноді суди формально констатують, що особа перебувала в уразливому стані, однак не пояснюють, чим він був зумовлений. Так, наприклад, Довгинцівський районний суд м. Кривого Рогу вказав, що Особа-2 з метою сексуальної експлуатації завербувала Особу-11, використовуючи її уразливий стан, однак не уточнив, чим саме він був зумовлений [109]. Вважаємо таку практику неприйнятною. Частіше, утім, трапляються ситуації, коли органи досудового розслідування та суди зазначають, що уразливий стан потерпілої особи зумовлений збігом тяжких особистих, сімейних або інших обставин, не конкретизуючи, однак, їх зміст. Для прикладу, Октябрський районний суд м. Полтави вказав, що потерпіла «Особа-3 потребувала грошових коштів, тобто перебувала в уразливому стані, а тому погодилася на запрошення надавати послуги інтимного характеру за матеріальну винагороду» [110]. Як видається, самої лише констатації того, що особа потребувала грошових коштів (на що? якої суми?), недостатньо для визнання факту перебування її в уразливому стані. Має рацію В.А. Козак, 
який підкреслює, що не будь-які особисті чи сімейні обставини можуть визнаватись причинами уразливого стану, а лише ті, яким іманентно притаманна реальна можливість у конкретній ситуації позбавити або обмежити здатність особи усвідомлювати свої дії (бездіяльність) або керувати ними ${ }^{1}$. Такими обставинами можуть бути визнані, приміром, тяжка хвороба рідних чи близьких, відсутність елементарних засобів для фізичного існування людини (житла, одягу, їжі) тощо [111, с. 76].

У судовій практиці іноді мають місце також випадки, коли суди детально з'ясовують наявність чи відсутність уразливого стану, в якому перебувала потерпіла особа. Так, приміром, Комінтернівський районний суд м. Харкова критично оцінив пояснення обвинуваченого Особа-5 в тій частині, що насправді потерпіла Особа-1 не перебувала в уразливому стані, оскільки під час зустрічей 3 ним пояснила, що є перукарем, має міжнародний сертифікат, крім того, на зустрічі завжди приходила охайно одягнена, з манікюром та зачіскою й хоча казала про потребу в грошах, але йому не було відомо про ії̈ матеріальне становище. Суд, однак, встановив, що під час зустрічей жінка неодноразово наголошувала на гострій потребі у грошах, оскільки на той час опинилась у скрутній ситуації, перебивалася випадковими заробітками 3 надання послуг манікюру, мала нагальну необхідність у значній сумі грошей для погашення боргів та для надання матеріальної допомоги неповнолітнім братам. У зв'язку з цим суд визнав, що Особа-1 перебувала в уразливому стані [112].

В іншому випадку Корольовський районний суд м. Житомира визнав невинуватим у вчиненні злочину, передбаченого ч. 2 ст. 149 КК України, Особу-3, зокрема, з огляду на те, що жоден з потерпілих, яких він начебто завербував для подальшої трудової експлуатації в Росії, не перебував в уразливому стані. Так, потерпілий Особа-10 повідомив, що до поїздки у Москву він працював підсобним робочим і отримував 50 гривень на день, тобто близько 1500 гривень на місяць, тоді як мінімальна заробітна плата в Україні на той час становила менше 1000 гривень на місяць. Суд підкреслив, що єдиною причиною поїздки потерпілих на роботу в Росію було їхнє бажання заробити більше грошей [113].

Зауважимо, що вітчизняному кримінальному закону відомий не тільки «уразливий» (ч. 1 ст. 149, ч. 1 ст. 258-1, ч. 1 ст. 303), а й «безпорадний» (п. 6 ч. 1 ст. 67, ч. 1 ст. 135, ч. 3 ст. 143 , ч. 2 ст. 144, ч. 3 ст. 314 ) стан. У спеціальній літературі висловлювались різні точки зору щодо їх співвідношення. Так, В.В.Кузнецов дійшов висновку, що термін «уразливий стан» доцільно замінити на звичний для вітчизняного законодавства i теорії права термін «безпорадний стан» [114, с. 717]. Разом з тим більш переконливою видається позиція тих авторів, які вважають, що зазначені терміни не $є$ тотожними за змістом $[18$, c. $144-146 ; 106$, c. $128-129 ; 115$,

1 Латвійський законодавець із цього приводу прямо вказує, що уразливий стан означає використання винним таких обставин, коли особа не має реального або прийнятного вибору, окрім як піддатися експлуатації (ч. 4 ст. 154-2 КК Латвії). Подібна вказівка міститься в кримінальному законодавстві Естонії (ч. 5 ст. 133). 
c. 318]. Наприклад, А. М. Орлеан слушно вказує на те, що безпорадний стан $є$ лише одним із проявів уразливого стану. Особа, яка перебуває в безпорадному стані, не дає згоди на те, щоб на неї впливали, оскільки або не усвідомлює характеру вчинюваних щодо неї дій, або не в змозі чинити опір насильницьким діям. У разі заміни в частині 2 примітки до ст. 149 КК України терміна «уразливий стан» на «безпорадний стан» поза межами криміналізації опиниться значна частина суспільно небезпечних діянь, спосіб вчинення яких пов'язаний 3 використанням стану, який може бути визнаний уразливим, але не $\epsilon$ безпорадним. Йдеться про соціальний уразливий стан, а також про активну форму фізіологічного уразливого стану, за якого особа хоч і обмежено, але все ж таки здатна усвідомлювати свої дії (бездіяльність) або керувати ними, приймати за своєю волею самостійні рішення, чинити опір насильницьким чи іншим незаконним діям [18, с. 145-146; 106, с. 129]. У цьому контексті зауважимо, що на відмінність між уразливим та безпорадним станом особи звертають увагу й деякі суди. Так, Івано-Франківський міський суд Івано-Франківської області вказав, що Особа-2, яка передала Особі-4 свого малолітнього сина для подальшої експлуатації у формі примусового зайняття жебрацтвом, використовувала «безпорадний та уразливий стан своєї дитини» [116].

Нагадаємо, що у 2018 р. диспозицію ч. 1 ст. 149 КК України доповнено трьома новими способами торгівлі людьми, вчиненої у вказаних вище формах: 1) з використанням примусу; 2) з використанням викрадення; 3) з використанням підкупу третьої особи, яка контролює потерпілого, для отримання згоди на його експлуатацію. Варто зазначити, що ще на етапі розгляду відповідного законопроекту зверталася увага на серйозні недоліки пропонованих змін. Так, Головне юридичне управління слушно вказувало, що введення у диспозицію ч. 1 ст. 149 КК України ознаки «використання примусу» породжуватиме конкуренцію 3 ч. 2 цієї статті, що передбачає посилену відповідальність за «дії, передбачені частиною першою ... поєднані 3 насильством, яке не $\epsilon$ небезпечним для життя чи здоров'я потерпілого чи його близьких, або з погрозою застосування такого насильства», а також із ч. 3 цієї ж статті, що встановлює відповідальність за «дії, передбачені частиною першою або другою цієї статті ... поєднані з насильством, небезпечним для життя або здоров'я потерпілого чи його близьких, або 3 погрозою застосування такого насильства» [50]. Варто також мати на увазі, що одним із способів примушування особи $\epsilon$ шантаж (про що йшлося вище), вказівка на який вже міститься в диспозиції ч. 1 ст. 149 КК України.

Критичні міркування стосовно зазначених змін висловлювалися і в науковій літературі $[53$, с. $58 ; 117$, c. 100]. Так, має рацію I.B. Сингаївська, яка вважає недоліком відтворення фактично дослівного тексту дефініції «торгівля людьми», що міститься у ст. 3 Палермського протоколу, в основному складі злочину, передбаченого ст. 149 КК України, без урахування особливостей диференціації кримінальної відповідальності за цей злочин [117, c. 100]. На наше переконання, прагнення будь-що максимально набли- 
зити формулювання диспозиції частини 1 вказаної статті до визначення торгівлі людьми, яке дається у згадуваних вище міжнародно-правових актах, призводить до ігнорування доцільності диференціації кримінальної відповідальності за досліджуване діяння. Механічне перенесення тексту міжнародно-правових норм у національний кримінальний закон навряд чи виправдане. Стосується це й наступного способу вчинення розглядуваного посягання - «з використанням викрадення». По-перше, відповідна ознака утворює конкуренцію зі ст. 146 КК, яка передбачає відповідальність за незаконне позбавлення волі або викрадення людини. У зв'язку з цим виключається кваліфікація за сукупністю злочинів, передбачених ст. 146 і ст. 149 КК України, а отже й призначення покарання за сукупністю злочинів. По-друге, 3 огляду на те, що обов'язковою ознакою викрадення людини є іï переміщення, виникає питання про співвідношення однієї з форм торгівлі людьми та аналізованого способу вчинення цього злочину. По-третє, 3 філологічної точки зору словосполучення «з використанням викрадення» $\epsilon$ некоректним $[50 ; 53$, с. 59; 117 , c. 100].

Ще одним способом вчинення торгівлі людьми у формах вербування, переміщення, переховування, передачі або одержання людини $\epsilon$ підкуп третьої особи, яка контролює потерпілого, для отримання згоди на його експлуатацію. Ще до прийняття законопроекту Головне юридичне управління вказувало на недоліки такого формулювання, зокрема на те, що недостатньо визначеним 3 юридичної точки зору $\epsilon$ поняття «контроль над потерпілим», що не відповідає вимогам щодо якості закону [50]. На невдалість законодавчого формулювання даного способу вчинення торгівлі людьми у зазначених вище формах зверталася увага i в науковій літературі. Так, А. М. Орлеан, проаналізувавши положення Конвенції Ради Європи про заходи щодо протидії торгівлі людьми та Палермського протоколу, дійшов слушного висновку, що у вказаних міжнародних документах йдеться не про якусь незацікавлену у цій ситуації третю особу, а про одного із суб'єктів злочину, який контролює та передає за плату жертву. Не витримує ніякої критики також ідея зазначення в диспозиції ч. 1 ст. 149 КК України суб'єкта злочину як третьої особи [53, с. 59]. І.В. Сингаївська, своєю чергою, обгрунтовано звертає увагу на те, що з тексту кримінального закону незрозуміло завдяки чому відповідна третя особа наділена повноваженнями контролювати іншу особу. Якщо завдяки своєму службовому становищу чи наділенню правами та обов'язками щодо виховання потерпілого, то зазначені випадки охоплюються іншими альтернативними (матеріальна чи інша залежність потерпілого) або ж кваліфікуючими (вчинення дій службовою особою з використанням службового становища) чи особливо кваліфікуючими (вчинення дій щодо неповнолітнього його батьками, усиновителями, опікунами чи піклувальниками) ознаками складу злочину $[117$, с. 100$]$.

3 огляду на викладене вважаємо, що доповнення диспозиції ч. 1 ст. 149 КК України трьома проаналізованими способами вчинення торгівлі людьми у формах вербування, переміщення, переховування, пере- 
дачі або одержання людини є невиправданим, оскільки неминуче призведе до нових проблем, пов'язаних 3 кваліфікацією розглядуваного діяння. Крім того, вказаний крок законодавця спричинив «захаращення» й без того громіздкої конструкції диспозиції ч. 1 ст. 149 КК України, що значно утруднює ії сприйняття.

Перенесення вказівки на такий спосіб вчинення досліджуваного діяння як «з використанням матеріальної чи іншої залежності потерпілого» 3 кваліфікованого до основного складу аналізованого злочину видається виправданим. На наш погляд, за ступенем суспільної небезпеки використання уразливого стану i використання матеріальної чи іншої залежності потерпілого є подібними. При цьому зазначимо, що за найбільш поширений і небезпечний різновид використання матеріальної чи іншої залежності потерпілого - вчинення розглядуваного діяння батьками щодо своїх дітей - законодавець обгрунтовано посилив відповідальність (у ч. 3 ст. 149 передбачено нову особливо кваліфікуючу ознаку торгівлі людьми - «дії, вчинені щодо неповнолітнього його батьками, усиновителями, опікунами чи піклувальниками») [30, с. 228; 31, с. 202].

У розглядуваному контексті необхідно зазначити, що в кримінально-правовій літературі висловлювалась думка про доцільність повної відмови від вказівки в диспозиції ч. 1 ст. 149 КК України на способи вчинення торгівлі людьми у формах вербування, переміщення, переховування, передачі або одержання лю- дини. Так, наприклад, А. С. Політова вважає, що вказівка на способи вчинення торгівлі людьми тільки перевантажує об'єктивну сторону злочину, а тому дане формулювання доцільно виключити з диспозиції зазначеної норми, що, своєю чергою, спростить правозастосування [8, с. 312]. Подібні доводи наводить також О.П. Горпинюк, яка додатковим аргументом на користь такого підходу вважає те, що в міжнародноправових актах визначення поняття «торгівля людьми» містить й інші способи, зокрема, окрім обману, ще й шахрайство, яке не передбачено в чинній ст. 149 КК України [12, с. 264]. Наведені аргументи не видаються переконливими. Відзначимо, що саме 3 огляду на обман, шантаж, перебування в уразливому стані і т. д. особа дає свою згоду на пропоновану їй роботу, на заняття проституцією тощо, і саме зважаючи на це, а також з огляду на мету подальшої експлуатації, навіть добровільна ії згода не виключає кримінальну відповідальність винного ${ }^{1}$. Виключення вказівки на спосіб вчинення аналізованого злочину, а також на мету експлуатації, що також пропонують окремі дослідники, призведе до того, що до торгівлі людьми доведеться зараховувати, приміром, діяльність будьяких агентств із працевлаштування. Зауважимо також, що доцільність закріплення способів вчинення вказаного злочину доведена напрацьованою на сьогодні правозастосовною практикою.

У кримінальному законодавстві окремих держав (наприклад, Ка-

1 У ст. 3 Палермського протоколу вказано, що «згода жертв торгівлі людьми на заплановану експлуатацію, про яку йдеться в підпункті (a) цієї статті, не береться до уваги, якщо було використано будь-який із заходів впливу, зазначених у підпункті (а)» [1]. 
захстану, Росії, Сальвадору, Узбекистану) дійсно немає вказівки на способи вчинення торгівлі людьми у формах вербування, переміщення, переховування, передачі або одержання людини ${ }^{1}$. Зауважимо, що зазначений підхід російського законодавця обгрунтовано критикується в науковій літературі. Приміром, О. В. Костилєва підкреслює, що згода жертви на експлуатацію не має значення для кваліфікації розглядуваного злочину, однак ця згода не береться до уваги лише в тому разі, якщо було використано будь-який із згаданих в Палермському протоколі способів. Скажімо, той факт, що потерпіла заздалегідь знала про те, що займатиметься проституцією, сам по собі ще не означає відсутності складу торгівлі людьми. Якщо потерпілу, яка була поінформована про характер роботи, змушують надавати сексуальні послуги на умовах, на які вона не погоджувалась, торгівля людьми має місце, оскільки застосовано обман [37, с. 64-65]. Таким чином, вказівка на способи торгівлі людьми у зазначених вище формах не тільки відповідає змісту цього діяння, як воно розуміється в Палермському протоколі, а й сприяє розмежуванню торгівлі людьми та інших складів злочинів [30, с. 229].

Висновки. Виходячи 3 викладеного вище, диспозицію частини 1 статті 149 КК України вважаємо за доцільне викласти у такій редакції:

«1. Купівля-продаж людини або здійснення іншої угоди щодо людини, а так само вчинені з метою експлуатації, з використанням обману або зловживання довірою, шантажу, матеріальної чи іншої залежності особи або ї̈ уразливого стану вербування, переміщення, переховування, передача або одержання людини».

\section{Список використаних джерел}

1. Протокол про запобігання та припинення торгівлі людьми, особливо жінками і дітьми, та покарання за неї, що доповнює Конвенцію ООН проти транснаціональної організованої злочинності, прийнятий резолюцією 55/25 Генеральної Асамблеї OОН від 15 листопада 2000 р. / Законодавство України. URL: https://zakon.rada.gov.ua/ laws/show/995_791\#Text

2. Конвенція Ради Європи про заходи щодо протидії торгівлі людьми від 16 травня 2005 р. / Законодавство України. URL: https://zakon.rada.gov.ua/laws/show/ 994_858\#Text

3. Козак В.А. Кримінальна відповідальність за торгівлю людьми (аналіз складу злочину): дис. ... канд. юрид. наук: 12.00.08. Харків, 2002. 196 с.

4. Лизогуб Я.Г. Кримінальна відповідальність за торгівлю людьми або іншу незаконну угоду щодо передачі людини: порівняльно-правове дослідження: автореф. дис. ... канд. юрид. наук: 12.00.08. Київ, 2003. 20 с.

1 Водночас законодавці деяких із вказаних держав встановлюють посилену відповідальність за торгівлю людьми, вчинену певними способами. Так, наприклад, узбецький законодавець у ч. 1 ст. 135 КК не наводить переліку способів вчинення даного злочину, однак серед обставин, які обтяжують відповідальність за торгівлю людьми, виокремлює викрадення, застосування насильства чи погрозу його застосування або інші форми примушування, використання підроблених документів, а також вилучення, приховування або знищення документів, що посвідчують особу потерпілого. 
5. Лизогуб Я.Г., Яценко С.С. Протидія торгівлі людьми: аналіз вітчизняного та зарубіжного законодавства: навч. посібник. Київ: Атіка, 2005. 240 с.

6. Орлеан А.М. Кримінально-правова характеристика торгівлі людьми. Монографія. Харків: СІМ, 2005. 180 с.

7. Коржанський М.Й. Кваліфікація злочинів: навчальний посібник. Київ: Атіка, 2007. $592 \mathrm{c}$.

8. Політова А.С. Практика притягнення до кримінальної відповідальності за статтею 149 КК та шляхи підвищення її ефективності. Науковий вісник Львівського державного університету внутрішніх справ. Серія юридична. 2013. Вип. 2. С. 306-314.

9. Скулиш Є. Структурні компоненти формування теоретичних основ протидії торгівлі людьми в Україні. Право України. 2010. № 4. С. 283-291.

10. Шевчук А.В., Дякур М.Д. Кримінальне право України (Особлива частина): навч. посіб. Чернівці: Чернівецький нац. ун-т, 2013. 472 с.

11. Вербенський М.Г., Мінка Т.П., Негодченко Д.О. Протидія торгівлі людьми в Україні: монографія. Дніпропетровськ: Дніпроп. держ. ун-т внутр. справ, 2010. 236 с.

12. Горпинюк О.П. Проблеми відповідальності за торгівлю людьми або іншу незаконну угоду щодо людини. Вісник Запорізького національного університету. Юридичні науки. 2014. № 4 (I). С. 261-267.

13. Кримінальне право (Особлива частина): підручник / за ред. 0.О. Дудорова, Є.О. Письменського. Київ: ВД «Дакор», 2013. 786 с.

14.Кримінальний кодекс України: науково-практичний коментар / відп. ред. Є.Л. Стрельцов. Харків: Одіссей, 2012. 904 с.

15.Науково-практичний коментар Кримінального кодексу України / за ред. M.I. Мельника, М.I. Хавронюка. Київ: ВД «Дакор», 2018. 1368 с.

16. Науково-практичний коментар до Кримінального кодексу України: у 2 т. Т. 1 / за заг. ред. П.П. Андрушка, В.Г. Гончаренка, Є.В. Фесенка. Київ: Алерта; КНТ; Центр учбової літератури, 2009. 964 с.

17.Негодченко Д.О. Юридичний аналіз структури злочину, передбаченого ст. 149 КК України. Науковий вісник Львівського державного університету внутрішніх справ. Серія юридична. 2011. Вип. 2. С. 306-316.

18.0рлеан А.М. Кримінально-правове забезпечення в Україні охорони людини від експлуатації: монографія. Кам'янець-Подільський: ПП Буйницький О.А., 2014. $456 \mathrm{c.}$

19.Стрекалов Є.Ф., Орлеан А.М. Теоретичні та практичні аспекти застосування ст. 149 Кримінального кодексу України. Вісник Верховного Суду України. 2006. № 9 (73). С. 30-35.

20. Іващенко В.О. Торгівля жінками та дітьми (кримінологічні та кримінальноправові аспекти боротьби). Монографія. Київ: Атіка, 2004. 112 с.

21. Науково-практичний коментар Кримінального кодексу України / за заг. ред. О.М. Джужі, А.В. Савченка, В.В. Чернєя. Київ: Юрінком Інтер, 2016. 1064 с.

22. Підгородинський В.М. Відповідальність за торгівлю людьми за кримінальним законодавством України: автореф. дис. ... канд. юрид. наук: 12.00.08. Одеса, 2005. $19 \mathrm{c}$.

23. Борисов B.I., Козак В.А. Торгівля людьми або інша незаконна угода щодо людини: характеристика складу злочину. Альманах кримінального права: збірник статей. Вип. 1 / відповід. ред. П.П. Андрушко, П.С. Берзін. Київ: Правова єдність, 2009. С. 151171.

24.Долголенко Т. Уголовная ответственность за торговлю людьми. Уголовное право. 2004. № 2. С. 23-25.

25. Карасёва М.Ю. Уголовная ответственность за преступления против свободы личности: дисс. ... канд. юрид. наук: 12.00.08. Москва, 2007. 186 с. 
26. Кислова Е.А. Проблемы регулирования уголовной ответственности за торговлю людьми. Уголовное право: стратегия развития в ХХІ веке: сб. материалов третьей Международной научно-практической конференции. Москва: МГЮА, 2006. С. 166-169.

27. Кримінальний кодекс України. Науково-практичний коментар: у 2 т. / за заг. ред. В.Я. Тація, В.П. Пшонки, В.І. Борисова, В.І. Тютюгіна. Т. 2: Особлива частина. Харків: Право, 2013. 1040 с.

28. Цивільний кодекс України від 16 січня 2003 р. № 435-IV / Законодавство України. URL: https://zakon.rada.gov.ua/laws/show/435-15\#Text

29.0рлеан А.М. Кримінально-правова кваліфікація торгівлі людьми: науковопрактичний коментар до ст. 149 КК України. Журнал східноєвропейського права. 2019. № 64. C. 28-40.

30.Андрушко А.В. Теоретико-прикладні засади запобігання та протидії злочинам проти волі, честі та гідності особи: монографія. Київ: Ваіте, 2020. 560 с.

31.Андрушко А.В. Злочини проти волі, честі та гідності особи (кримінальноправове та кримінологічне дослідження): дис. ... докт. юрид. наук: 12.00.08. Ужгород, 2021. 675 c.

32.Гулякевич Д.Л. Уголовно-правовая охрана ребенка в Республике Беларусь: автореф. дисс. ... канд. юрид. наук: 12.00.08. Москва, 2015. 44 с.

33. Дмитриев О. Уголовно-правовая характеристика торговли несовершеннолетними. Уголовное право. 2002. № 3. С. 14-16.

34.Егорова Л.Ю. Торговля несовершеннолетними: проблемы квалификации: автореф. дисс. ... канд. юрид. наук: 12.00.08. Москва, 2007. 29 с.

35.Измайлова И.Д. Уголовная ответственность за торговлю людьми: автореф. дисс. ... канд. юрид. наук: 12.00.08. Москва, 2007. 26 с.

36.Измайлова И.Д. Уголовная ответственность за торговлю людьми: дисс. ... канд. юрид. наук: 12.00.08. Москва, 2007. 220 с.

37. Костылева О.В. Торговля людьми: имплементация международно-правовых норм и вопросы квалификации преступления по ст. 127-1 УК РФ. Вестник Московского университета. Серия 11. Право. 2013. № 3. С. 56-73.

38. Нєбитов А.А. Сексуальна експлуатація в Україні: кримінально-правовий та кримінологічний аналіз: монографія. Київ: Освіта України, 2016. 464 с.

39. Пудовочкин Ю.Е. Ответственность за преступления против несовершеннолетних по российскому уголовному праву. Санкт-Петербург: Юридический центр Пресс, 2002. 293 с.

40. Факультативний протокол до Конвенції про права дитини щодо торгівлі дітьми, дитячої проституції і дитячої порнографії від 1 січня 2000 р. / Законодавство України. URL: https://zakon.rada.gov.ua/laws/show/995_b09\#Text

41. Кулакова Н.Г. Криминологические и уголовно-правовые меры борьбы с торговлей несовершеннолетними: автореф. дисс. ... канд. юрид. наук: 12.00.08. Москва, 2000. 22 c.

42. Нагачевська Ю.С. Кримінально-правова характеристика торгівлі жінками 3 метою сексуальної експлуатації. Науковий вісник Львівського державного університету внутрішніх справ. Серія юридична. 2014. Вип. 4. С. 241-253.

43.Борисов B.I. Вибрані твори / уклад.: В.В.Базелюк, С.В. Гізімчук, Л.М. Демидова та ін.. Харків: Право, 2018. 784 с.

44.Борисов B.I., Козак В.А. Коментар до статті 149 Кримінального кодексу України (в редакції Закону від 12 січня 2006 р.). Кримінальне право України. 2006. № 2. C. 17-23. 
45.Іващенко В.О. Кримінологічні та кримінально-правові аспекти боротьби 3 торгівлею жінками та дітьми: автореф. дис. ... канд. юрид. наук: 12.00.08. Київ, 2000. $19 \mathrm{c}$.

46. Жинкин А.А. Торговля людьми и использование рабского труда: проблемы квалификации и соотношение со смежными составами преступлений: дисс. ... канд. юрид. наук: 12.00.08. Краснодар, 2005. 192 с.

47. Іскров К. Об'єктивна сторона складу злочину «торгівля людьми» або інша незаконна угода щодо людини (ст. 149 Кримінального кодексу України). Підприємництво, господарство і право. 2012. № 3 (195). С. 116-120.

48. Митрофанов I.I. Торгівля людьми: кримінально-правове визначення поняття. Науковий вісник Міжнародного гуманітарного університету. 2012. № 3. С. 118-123.

49. Негодченко Д.О. Кримінальна відповідальність за торгівлю людьми в Україні та інших країнах: порівняльно-правовий аналіз: автореф. дис. ... канд. юрид. наук: 12.00.08. Харків, 2011. 22 с.

50.Зауваження до проекту Закону України «Про внесення змін до статті 149 Кримінального кодексу України щодо приведення у відповідність з міжнародними стандартами» / Верховна Рада України: офіційний веб-портал. URL: http://w1.c1.rada.gov.ua/pls/zweb2/webproc4_1?pf3511=61428

51.Закон України «Про внесення зміни до статті 149 Кримінального кодексу України щодо приведення у відповідність 3 міжнародними стандартами» від 6 вересня 2018 p. № 2539-VIII / Законодавство України. URL: https://zakon.rada.gov.ua/laws/show/2539-19\#Text

52.Пояснювальна записка до проекту Закону України «Про внесення змін до статті 149 Кримінального кодексу України (щодо приведення у відповідність до міжнародних стандартів» / Верховна Рада України: офіційний веб-портал. URL: http://w1.c1.rada.gov.ua/pls/zweb2/webproc4_1?pf3511=61428

53. Орлеан А.М. Редакція статті 149 КК України може змінитись вже в четвертий раз (про доцільність приведення кримінальної відповідальності за торгівлю людьми у відповідність до міжнародних та європейських стандартів). Журнал східноєвропейського права. 2017. № 46. С. 55-61.

54. Козак В.А. Нова редакція кримінального закону, що передбачає відповідальність за торгівлю людьми: проблеми тлумачення та застосування. Ефективність кримінального законодавства: доктринальні, законотворчі та правозастосовні проблеми ї̈ забезпечення: матер. міжнарод. наук.-практ. кругл. столу (м. Харків, 17 трав. 2019 р.). Харків: Константа, 2019. С. 142-145.

55.Яремко Г.3. Бланкетні диспозиції в статтях Особливої частини Кримінального кодексу України: монографія / за ред. В.О. Навроцького. Львів: Львівський державний університет внутрішніх справ, 2011. 424 с.

56. Ясечко С.В. Генеза поняття «правочин» у цивільному праві. Університетські наукові записки. 2014. № 4 (52). С. 80-87.

57. Великий тлумачний словник сучасної української мови (з дод. і допов.) / уклад. і голов. ред. В.Т. Бусел. Київ; Ірпінь: ВТФ «Перун», 2005. 1728 с.

58. Борисов B.I. Злочини проти волі, честі та гідності особи. Злочини проти статевої свободи та статевої недоторканості (Лекція 6 та 7). Харків: Видавець ФО-П Вапнярчук Н.М., 2008. 32 с.

59. Кваліфікація злочинів, підслідних органам внутрішніх справ: навчальний посібник / за заг. ред. В.В. Коваленка; за наук. ред. О.М. Джужи та А.В. Савченка. Київ: Атіка, 2011. 648 с.

60.Вирок Бориспільського міськрайонного суду Київської обл. від 25 грудня 2014 р. (справа № 359/12163/14-к) / Єдиний державний реєстр судових рішень. URL: http://reyestr.court.gov.ua/Review/42063553 
61. Вирок Залізничного районного суду м. Львова від 25 квітня 2018 р. (справа № 462/4857/17) / Єдиний державний реєстр судових рішень. URL: http://reyestr.court.gov.ua/Review/73612297

62. Приговор Приморского районного суда г. Одессы от 18 октября 2012 г. (дело № 1522/13573/12) / Єдиний державний реєстр судових рішень. URL: http://reyestr.court.gov.ua/Review/27289237

63. Приговор Кировского районного суда г. Днепропетровска от 11 июля 2013 г. (дело № 0418/1345/2012) / Єдиний державний реєстр судових рішень. URL: http://reyestr.court.gov.ua/Review/32835647

64.Вирок Приморського районного суду м. Одеси від 18 грудня 2013 р. (справа №522/13514/13-к) / Єдиний державний реєстр судових рішень. URL: http://reyestr.court.gov.ua/Review/36201392

65. Вирок Ленінського районного суду м. Харкова від 25 березня 2014 р. (справа №642/2243/14-к) / Єдиний державний реєстр судових рішень. URL: http://reyestr.court.gov.ua/Review/37816036

66. Вирок Нікопольського міськрайонного суду Дніпропетровської обл. від 8 квітня 2014 р. (справа № 182/700/16-к) / Єдиний державний реєстр судових рішень. URL: http://reyestr.court.gov.ua/Review/57029928

67. Вирок Котовського міськрайонного суду Одеської обл. від 29 червня 2017 р. (справа № 505/1335/17) / Єдиний державний реєстр судових рішень. URL: http://reyestr.court.gov.ua/Review/67446334

68. Вирок Приморського районного суду м. Одеси від 23 квітня 2018 р. (справа № 522/12410/15-к) / Єдиний державний реєстр судових рішень. URL: http://reyestr.court.gov.ua/Review/73743400

69.Вирок Мар'їнського районного суду Донецької обл. від 25 жовтня 2013 р. (справа № 237/67/13-к) / Єдиний державний реєстр судових рішень. URL: http://reyestr.court.gov.ua/Review/36845086

70. Вирок Київського районного суду м. Донецька від 13 березня 2014 р. (справа № 257/12350/13-к) / Єдиний державний реєстр судових рішень. URL: http://reyestr.court.gov.ua/Review/38127148

71.0 практике применения законодательства, устанавливающего ответственность за торговлю людьми. Нормативное постановление Верховного Суда Республики Казахстан от 29 декабря 2012 г. № 7 / Информационно-правовая система нормативных правовых актов Республики Казахстан. URL: http://adilet.zan.kz/rus/docs/P120000007S

72. Вирок Солом'янського районного суду м. Києва від 26 серпня 2010 р. (справа № 1-837/2010) / Єдиний державний реєстр судових рішень. URL: http://reyestr.court.gov.ua/Review/51117927

73.Вирок Центрально-Міського районного суду м. Кривого Рогу від 27 квітня 2016 р. (справа № 216/513/15-к) / Єдиний державний реєстр судових рішень. URL: http://reyestr.court.gov.ua/Review/57478543

74.Приговор Долгинцевского районного суда г. Кривого Рога Днепропетровской обл. от 30 ноября 2010 г. (дело № 1-452/10) / Єдиний державний реєстр судових рішень. URL: http://reyestr.court.gov.ua/Review/53472371

75. Приговор Краснодонского горрайонного суда Луганской обл. от 26 апреля 2011 г. (дело № 1-377/11) / Єдиний державний реєстр судових рішень. URL: http://reyestr.court.gov.ua/Review/15361205

76. Буряк М.Ю. Торговля людьми и борьба с ней (криминологические и уголовно-правовые аспекты): дисс. ... канд. юрид. наук: 12.00.08. Владивосток, 2005. 246 с. 
77. Політова А.С. Кримінально-правова характеристика злочинів проти свободи особи за законодавством України: автореф. дис. ... канд. юрид. наук: 12.00.08. Київ, 2007. 20 c.

78. Вирок Луцького міськрайонного суду Волинської обл. від 26 квітня 2018 р. (справа №161/14645/13-к) / Єдиний державний реєстр судових рішень. URL: http://reyestr.court.gov.ua/Review/73661853

79. Вирок Синельниківського міськрайонного суду Дніпропетровської обл. від 9 грудня 2011 р. (справа № 1-305/11) / Єдиний державний реєстр судових рішень. URL: http://reyestr.court.gov.ua/Review/20124666

80. Вирок Новоукраїнського районного суду Кіровоградської обл. від 31 травня 2011 р. (справа № 1-103/11) / Єдиний державний реєстр судових рішень. URL: http://reyestr.court.gov.ua/Review/15987093

81. Бекмагамбетов А.Б. Правовые основы криминализации торговли людьми в уголовном законодательстве Республики Казахстан: автореф. дисс. ... канд. юрид. наук: 12.00.08. Челябинск, 2005. 26 с.

82.Бухориев Б.Р. Уголовно-правовые меры предупреждения торговли людьми (по материалам Республики Таджикистан): дисс. ... канд. юрид. наук: 12.00.08. Москва, 2018. 242 c.

83.Горбань Е.Г. Противодействие торговле людьми (уголовно-правовой и криминологический аспекты): дисс. ... канд. юрид. наук: 12.00.08. Москва, 2012.195 с.

84.Ищенко Г.К. Уголовно-правовые и криминологические меры противодействия торговле людьми и использованию рабского труда: дисс. ... канд. юрид. наук: 12.00.08. Ростов-на-Дону, 2010. 210 с.

85. Кислова Е.А. Уголовно-правовые средства противодействия рабству и торговле людьми: дисс. ... канд. юрид. наук: 12.00.08. Москва, 2005. 167 с.

86. Бухориев Б.Р. Уголовно-правовые меры предупреждения торговли людьми (по материалам Республики Таджикистан): автореф. дисс. ... канд. юрид. наук: 12.00.08. Москва, 2018. 24 с.

87.Горбань Е.Г. Противодействие торговле людьми (уголовно-правовой и криминологический аспекты): автореф. дисс. ... канд. юрид. наук: 12.00.08. Москва, 2012. $29 \mathrm{c}$.

88.Зайдиева Д.Я. Уголовно-правовая охрана личной свободы человека: дисс. ... канд. юрид. наук: 12.00.08. Москва, 2006. 181 с.

89. Кадников Ф.Н. Криминологическая характеристика и предупреждение преступлений, связанных с торговлей людьми: автореф. дисс. ... канд. юрид. наук: 12.00.08. Москва, 2007. 26 с.

90. Кислова Е.А. Уголовно-правовые средства противодействия рабству и торговле людьми: дисс. ... канд. юрид. наук: 12.00.08. Москва, 2005. 167 с.

91.Смирнов Ю.П. Уголовная ответственность за сексуальную эксплуатацию других лиц в форме занятия ими проституцией: автореф. дисс. ... канд. юрид. наук: 12.00.08. Москва, 2010. 24 с.

92. Шалимов Е.Е. Уголовно-правовые и криминологические проблемы торговли людьми: автореф. дисс. ... канд. юрид. наук: 12.00.08. Саратов, 2007. 29 с.

93. Панов Н.И. Квалификация преступлений, совершаемых путём обмана: учеб. пособие. Харьков: Юридический институт, 1980. 88 с.

94.Романов С.Ю. Обман як спосіб злочинної діяльності: автореф. дис. ... канд. юрид. наук: 12.00.08. Харків, 1998. 16 с.

95. Максимович Р. Обман як наскрізне кримінально-правове поняття. Вісник Львівського університету. Серія юридична. 2019. Вип. 69. С. 153-160. 
96.Анісімов Г.М. Зловживання довірою як спосіб вчинення злочину: поняття і кримінально-правове значення: автореф. дис. ... канд. юрид. наук: 12.00.08. Харків, 2003. 20 c.

97. Анісімов Г.М. Зловживання довірою як спосіб учинення злочину. Проблеми законності. 2015. Вип. 128. С. 20-28.

98. Тростюк 3. Про необхідність тлумачення поняття «шантаж» у Кримінальному кодексі України. Проблеми державотворення і захисту прав людини в Україні: матеріали IX регіональної наук.-практ. конференції, 13-14 лютого 2003 р. Львів: Юридичний факультет ЛНУ ім. Івана Франка, 2003. С. 463-464.

99.Загиней 3.А. Герменевтика кримінального закону України: дис. ... докт. юрид. наук: 12.00.08. Київ, 2016. 636 с.

100. Зінченко I.O., Самощенко І.В. Про поняття шантажу в кримінальному праві. Кримінальне право Украӥни. 2006. № 9. С. 3-8.

101. Самощенко I.В. Характеристика шантажу за кримінальним правом України та зарубіжних країн. Науковий вісник Міжнародного гуманітарного університету. Серія: Юриспруденція. 2019. Вип. 39. С. 102-106.

102. Ганченко О.И. Понятие шантажа в уголовном праве. Общество и право. 2011. № 5 (37). С. 163-165.

103. Ізетов А.Е. Втягнення у вчинення терористичного акту: кримінальноправове дослідження: монографія. Харків: Право, 2010.174 с.

104. Приговор Алчевского городского суда Луганской обл. от 25 сентября 2012 г. (дело № 1-501/12) / Єдиний державний реєстр судових рішень. URL: http://www.reyestr.court.gov.ua/Review/27426031

105. Вирок Бородянського районного суду Київської обл. від 8 червня 2012 р. (справа № 1006/1318/2012) / Єдиний державний реєстр судових рішень. URL: http://reyestr.court.gov.ua/Review/24510364

106. Орлеан А. Використання уразливого стану як форма впливу на особу з метою її експлуатації: проблеми теорії та практики. Публічне право. 2013. № 4 (12). C. $127-134$.

107. Вирок Глухівського міськрайонного суду Сумської обл. від 27 грудня 2017 p. / Єдиний державний реєстр судових рішень. URL: http://reyestr.court.gov.ua/Review/71258147

108. Вирок Ковпаківського районного суду м. Суми від 3 жовтня 2018 р. (справа № 592/7803/18) / Єдиний державний реєстр судових рішень. URL: http://reyestr.court.gov.ua/Review/76890496

109. Вирок Довгинцівського районного суду м. Кривого Рогу від 30 листопада 2010 р. (справа № 1-452/10) / Єдиний державний реєстр судових рішень. URL: http://reyestr.court.gov.ua/Review/53472371

110. Вирок Октябрського районного суду м. Полтави від 13 червня 2018 р. (справа №554/3896/18) / Єдиний державний реєстр судових рішень. URL: http://reyestr.court.gov.ua/Review/74653292

111. Козак В.А. Уразливий стан особи за кримінальним правом України: зміст та співвідношення з іншими суміжними поняттями. Збірник наукових праць Харківського національного педагогічного університету імені Г.С. Сковороди. «Право». 2013. Вип. 20. С. 73-80.

112. Вирок Комінтернівського районного суду м. Харкова від 31 січня 2017 р. (справа №641/7721/15-к) / Єдиний державний реєстр судових рішень. URL: http://reyestr.court.gov.ua/Review/64414090

113. Вирок Корольовського районного суду м. Житомира від 29 березня 2013 р. (справа № 296/407/12-к) / Єдиний державний реєстр судових рішень. URL: http://reyestr.court.gov.ua/Review/30385979 
114. Кузнецов В.В. Кримінально-правова охорона громадського порядку та моральності в українському вимірі: монографія. Київ: ТОВ НВП «Інтерсервіс», 2012. 908 c.

115. Максимович Р.Л. Про співвідношення понять «уразливий стан» і «безпорадний стан» у кримінальному праві України. Основні напрями розвитку кримінального права та шляхи вдосконалення законодавства України про кримінальну відповідальність: матеріали міжнар. наук.-практ. конф., 11-12 жовт. 2012 р. Харків: Право, 2012. С. 316-318.

116. Вирок Івано-Франківського міського суду Івано-Франківської обл. від 11 березня 2011 р. (справа № 0907/1-234/2011) / Єдиний державний реєстр судових рішень. URL: http://reyestr.court.gov.ua/Review/15051076

117. Сингаївська І. В. Особливості регламентації кримінальної відповідальності за торгівлю людьми. Вчені записки Таврійського національного університету імені B.I. Вернадського. Серія: юридичні науки. 2019. Том 30 (69). № 1. С. 98-102.

\section{References}

Kozak, V.A. (2002). Kryminalna vidpovidalnist za torhivliu liudmy (analiz skladu zlochynu): dys. ... kand. yuryd. nauk: 12.00.08. Kharkiv [in Ukrainian].

Lyzohub, Ya.H. (2003). Kryminalna vidpovidalnist za torhivliu liudmy abo inshu nezakonnu uhodu shchodo peredachi liudyny: porivnialno-pravove doslidzhennia: avtoref. dys. ... kand. yuryd. nauk: 12.00.08. Kyiv [in Ukrainian].

Lyzohub, Ya.H., Yatsenko, S.S. (2005). Protydiia torhivli liudmy: analiz vitchyznianoho ta zarubizhnoho zakonodavstva. Kyiv: Atika [in Ukrainian].

Orlean, A.M. (2005). Kryminalno-pravova kharakterystyka torhivli liudmy. Kharkiv: SIM [in Ukrainian].

Korzhanskyi, M.I. (2007). Kvalifikatsiia zlochyniv. Kyiv: Atika [in Ukrainian].

Politova, A.S. (2013). Praktyka prytiahnennia do kryminalnoi vidpovidalnosti za statteiu $149 \mathrm{KK}$ ta shliakhy pidvyshchennia yii efektyvnosti. Naukovyi visnyk Lvivskoho derzhavnoho universytetu vnutrishnikh sprav. Seriia yurydychna, 2, 306-314 [in Ukrainian].

Skulysh, Ye. (2010). Strukturni komponenty formuvannia teoretychnykh osnov protydii torhivli liudmy v Ukraini. Pravo Ukrainy, 4, 283-291 [in Ukrainian].

Shevchuk, A.V., Diakur, M.D. (2013). Kryminalne pravo Ukrainy (Osoblyva chastyna): navch. posib. Chernivtsi: Chernivetskyi nats. un-t [in Ukrainian].

Verbenskyi, M.H., Minka, T.P., Nehodchenko, D.O. (2010). Protydiia torhivli liudmy v Ukraini. Dnipropetrovsk: Dniprop. derzh. un-t vnutr. sprav [in Ukrainian].

Horpyniuk, O.P. (2014). Problemy vidpovidalnosti za torhivliu liudmy abo inshu nezakonnu uhodu shchodo liudyny. Visnyk Zaporizkoho natsionalnoho universytetu. Yurydychni nauky, 4 (I), 261-267 [in Ukrainian].

Dudorov, O.O., Pysmenskyi, Ye.O. (Red.). (2013). Kryminalne pravo (Osoblyva chastyna): pidruchnyk. Kyiv: VD «Dakor» [in Ukrainian].

Streltsov, Ye.L. (Red.). (2012). Kryminalnyi kodeks Ukrainy: naukovo-praktychnyi komentar. Kharkiv: Odissei [in Ukrainian].

Melnyk, M.I., Khavroniuk, M.I. (Red.). (2018). Naukovo-praktychnyi komentar Kryminalnoho kodeksu Ukrainy. Kyiv: VD «Dakor» [in Ukrainian].

Andrushko, P.P., Honcharenko, V.H., Fesenko, Ye.V. (Red.). (2009). Naukovopraktychnyi komentar do Kryminalnoho kodeksu Ukrainy: u 2 t. T. 1. Kyiv: Alerta; KNT; Tsentr uchbovoi literatury [in Ukrainian].

Nehodchenko, D.O. (2011). Yurydychnyi analiz struktury zlochynu, peredbachenoho st. 149 KK Ukrainy. Naukovyi visnyk Lvivskoho derzhavnoho universytetu vnutrishnikh sprav. Seriia yurydychna, Vyp. 2, 306-316 [in Ukrainian]. 
Orlean, A.M. (2014). Kryminalno-pravove zabezpechennia v Ukraini okhorony liudyny vid ekspluatatsii. Kamianets-Podilskyi: PP Buinytskyi O.A. [in Ukrainian].

Strekalov, Ye.F., Orlean, A.M. (2006). Teoretychni ta praktychni aspekty zastosuvannia st. 149 Kryminalnoho kodeksu Ukrainy. Visnyk Verkhovnoho Sudu Ukrainy, 9 (73), 30-35 [in Ukrainian].

Ivashchenko, V.O. (2004). Torhivlia zhinkamy ta ditmy (kryminolohichni ta kryminalno-pravovi aspekty borotby). Monohrafiia. Kyiv: Atika [in Ukrainian].

Dzhuzha, O.M., Savchenko, A.V., Cherniei, V.V. (Red.). (2016). Naukovo-praktychnyi komentar Kryminalnoho kodeksu Ukrainy. Kyiv: Yurinkom Inter [in Ukrainian].

Pidhorodynskyi, V.M. (2005). Vidpovidalnist za torhivliu liudmy za kryminalnym zakonodavstvom Ukrainy: avtoref. dys. ... kand. yuryd. nauk: 12.00.08. Odesa [in Ukrainian].

Borysov, V.I., Kozak, V.A. (2009). Torhivlia liudmy abo insha nezakonna uhoda shchodo liudyny: kharakterystyka skladu zlochynu. Almanakh kryminalnoho prava: zbirnyk statei. Vyp. 1 / vidpovid. red. P.P. Andrushko, P.S. Berzin. Kyiv: Pravova yednist, 151-171 [in Ukrainian].

Dolgolenko, T. (2004). Ugolovnaya otvetstvennost' za torgovlyu lyud'mi. Ugolovnoe pravo, 2, 23-25 [in Russian].

Karasyova, M.Yu. (2007). Ugolovnaya otvetstvennost' za prestupleniya protiv svobody lichnosti: diss. ... kand. yurid. nauk: 12.00.08. Moskva [in Russian].

Kislova, E.A. (2006). Problemy regulirovaniya ugolovnoj otvetstvennosti za torgovlyu lyud'mi. Ugolovnoe pravo: strategiya razvitiya $v$ XXI veke: $\mathrm{sb}$. materialov tret'ej Mezhdunarodnoj nauchno-prakticheskoj konferencii. Moskva: MGYUA, 166-169 [in Russian].

Tatsii, V.Ia., Pshonka, V.P., Borysov, V.I., Tiutiuhin, V.I. (Red.). (2013). Kryminalnyi kodeks Ukrainy. Naukovo-praktychnyi komentar: u 2 t. T. 2: Osoblyva chastyna. Kharkiv: Pravo [in Ukrainian].

Orlean, A.M. (2019). Kryminalno-pravova kvalifikatsiia torhivli liudmy: naukovopraktychnyi komentar do st. 149 KK Ukrainy. Zhurnal skhidnoievropeiskoho prava, 64, 28-40 [in Ukrainian].

Andrushko, A.V. (2020). Teoretyko-prykladni zasady zapobihannia ta protydii zlochynam proty voli, chesti ta hidnosti osoby. Kyiv: Vaite [in Ukrainian].

Andrushko, A.V. (2021). Zlochyny proty voli, chesti ta hidnosti osoby (kryminalnopravove ta kryminolohichne doslidzhennia): dys. ... dokt. yuryd. nauk: 12.00.08. Uzhhorod [in Ukrainian].

Gulyakevich, D.L. (2015). Ugolovno-pravovaya ohrana rebenka v Respublike Belarus': avtoref. diss. ... kand. yurid. nauk: 12.00.08. Moskva [in Russian].

Dmitriev, O. (2002). Ugolovno-pravovaya harakteristika torgovli nesovershennoletnimi. Ugolovnoe pravo, 3, 14-16 [in Russian].

Egorova, L.Yu. (2007). Torgovlya nesovershennoletnimi: problemy kvalifikacii: avtoref. diss. ... kand. yurid. nauk: 12.00.08. Moskva [in Russian].

Izmajlova, I.D. (2007). Ugolovnaya otvetstvennost' za torgovlyu lyud'mi: avtoref. diss. ... kand. yurid. nauk: 12.00.08. Moskva, 2007 [in Russian].

Kostyleva, O.V. (2013). Torgovlya lyud'mi: implementaciya mezhdunarodnopravovyh norm i voprosy kvalifikacii prestupleniya po st. 127-1 UK RF. Vestnik Moskovskogo universiteta. Seriya 11. Pravo, 3, 56-73 [in Russian].

Niebytov, A.A. (2016). Seksualna ekspluatatsiia v Ukraini: kryminalno-pravovyi ta kryminolohichnyi analiz. Kyiv: Osvita Ukrainy [in Ukrainian].

Pudovochkin, Yu.E. (2002). Otvetstvennost' za prestupleniya protiv nesovershennoletnih po rossijskomu ugolovnomu pravu. Sankt-Peterburg: Yuridicheskij centr Press [in Russian]. 
Kulakova, N.G. (2000). Kriminologicheskie i ugolovno-pravovye mery bor'by s torgovlej nesovershennoletnimi: avtoref. diss. ... kand. yurid. nauk: 12.00.08. Moskva [in Russian].

Nahachevska, Yu.S. (2014). Kryminalno-pravova kharakterystyka torhivli zhinkamy z metoiu seksualnoi ekspluatatsii. Naukovyi visnyk Lvivskoho derzhavnoho universytetu vnutrishnikh sprav. Seriia yurydychna, Vyp. 4, 241-253 [in Ukrainian].

Borysov, V.I. (2018). Vybrani tvory. Kharkiv: Pravo [in Ukrainian].

Borysov, V.I., Kozak, V.A. (2006). Komentar do statti 149 Kryminalnoho kodeksu Ukrainy (v redaktsii Zakonu vid 12 sichnia 2006 r.). Kryminalne pravo Ukrainy, 2, 17-23 [in Ukrainian].

Ivashchenko, V.O. (2000). Kryminolohichni ta kryminalno-pravovi aspekty borotby $z$ torhivleiu zhinkamy ta ditmy: avtoref. dys. ... kand. yuryd. nauk: 12.00.08. Kyiv [in Ukrainian].

Zhinkin, A.A. (2005). Torgovlya lyud'mi $i$ ispol'zovanie rabskogo truda: problemy kvalifikacii i sootnoshenie so smezhnymi sostavami prestuplenij: diss. ... kand. yurid. nauk: 12.00.08. Krasnodar [in Russian].

Iskrov, K. (2012). Obiektyvna storona skladu zlochynu «torhivlia liudmy» abo insha nezakonna uhoda shchodo liudyny (st. 149 Kryminalnoho kodeksu Ukrainy). Pidpryiemnytstvo, hospodarstvo i pravo, 3 (195), 116-120 [in Ukrainian].

Mytrofanov, I.I. (2012). Torhivlia liudmy: kryminalno-pravove vyznachennia poniattia. Naukovyi visnyk Mizhnarodnoho humanitarnoho universytetu, 3, 118-123 [in Ukrainian].

Nehodchenko, D.0. (2011). Kryminalna vidpovidalnist za torhivliu liudmy v Ukraini ta inshykh krainakh: porivnialno-pravovyi analiz: avtoref. dys. ... kand. yuryd. nauk: 12.00.08. Kharkiv [in Ukrainian].

Orlean, A.M. (2017). Redaktsiia statti 149 KK Ukrainy mozhe zminytys vzhe v chetvertyi raz (pro dotsilnist pryvedennia kryminalnoi vidpovidalnosti za torhivliu liudmy $\mathrm{u}$ vidpovidnist do mizhnarodnykh ta yevropeiskykh standartiv). Zhurnal skhidnoievropeiskoho prava, 46, 55-61 [in Ukrainian].

Kozak, V.A. (2019). Nova redaktsiia kryminalnoho zakonu, shcho peredbachaie vidpovidalnist za torhivliu liudmy: problemy tlumachennia ta zastosuvannia. Efektyvnist kryminalnoho zakonodavstva: doktrynalni, zakonotvorchi ta pravozastosovni problemy yii zabezpechennia: mater. mizhnarod. nauk.-prakt. kruhl. stolu (m. Kharkiv, 17 trav. 2019 r.). Kharkiv: Konstanta, 142-145 [in Ukrainian].

Yaremko, H.Z. (2011). Blanketni dyspozytsii $v$ stattiakh Osoblyvoi chastyny Kryminalnoho kodeksu Ukrainy / za red. V.O. Navrotskoho. Lviv: Lvivskyi derzhavnyi universytet vnutrishnikh sprav [in Ukrainian].

Yasechko, S.V. (2014). Geneza poniattia «pravochyn» u tsyvilnomu pravi. Universytetski naukovi zapysky, 4 (52), 80-87 [in Ukrainian].

Busel, V.T. (Red.). (2005). Velykyi tlumachnyi slovnyk suchasnoi ukrainskoi movy (z dod. i dopov.). Kyiv; Irpin: VTF «Perun» [in Ukrainian].

Borysov, V.I. (2008). Zlochyny proty voli, chesti ta hidnosti osoby. Zlochyny proty statevoi svobody ta statevoi nedotorkanosti (Lektsiia 6 ta 7). Kharkiv: Vydavets FO-P Vapniarchuk N.M. [in Ukrainian].

Kovalenko, V.V. (Red.). (2011). Kvalifikatsiia zlochyniv, pidslidnykh orhanam vnutrishnikh sprav: navchalnyi posibnyk. Kyiv: Atika, 2011 [in Ukrainian].

Buryak, M.Yu. (2005). Torgovlya lyud'mi i bor'ba s nej (kriminologicheskie i ugolovnopravovye aspekty): diss. ... kand. yurid. nauk: 12.00.08. Vladivostok [in Russian].

Politova, A.S. (2007). Kryminalno-pravova kharakterystyka zlochyniv proty svobody osoby za zakonodavstvom Ukrainy: avtoref. dys. ... kand. yuryd. nauk: 12.00.08. Kyiv [in Ukrainian]. 
Bekmagambetov, A.B. (2005). Pravovye osnovy kriminalizacii torgovli lyud'mi $v$ ugolovnom zakonodatel'stve Respubliki Kazahstan: avtoref. diss. ... kand. yurid. nauk: 12.00.08. Chelyabinsk [in Russian].

Buhoriev, B.R. (2018). Ugolovno-pravovye mery preduprezhdeniya torgovli lyud'mi (po materialam Respubliki Tadzhikistan): diss. ... kand. yurid. nauk: 12.00.08. Moskva [in Russian].

Gorban', E.G. (2012). Protivodejstvie torgovle lyud'mi (ugolovno-pravovoj $i$ kriminologicheskij aspekty): diss. ... kand. yurid. nauk: 12.00.08. Moskva [in Russian].

Ishchenko, G.K. (2010). Ugolovno-pravovye i kriminologicheskie mery protivodejstviya torgovle lyud'mi i ispol'zovaniyu rabskogo truda: diss. ... kand. yurid. nauk: 12.00.08. Rostovna-Donu [in Russian].

Kislova, E.A. (2005). Ugolovno-pravovye sredstva protivodejstviya rabstvu i torgovle lyud'mi: diss. ... kand. yurid. nauk: 12.00.08. Moskva [in Russian].

Zajdieva, D.Ya. (2006). Ugolovno-pravovaya ohrana lichnoj svobody cheloveka: diss. ... kand. yurid. nauk: 12.00.08. Moskva [in Russian].

Kadnikov, F.N. (2007). Kriminologicheskaya harakteristika i preduprezhdenie prestuplenij, svyazannyh s torgovlej lyud'mi: avtoref. diss. ... kand. yurid. nauk: 12.00.08. Moskva [in Russian].

Smirnov, Yu.P. (2010). Ugolovnaya otvetstvennost' za seksual'nuyu ekspluataciyu drugih lic $v$ forme zanyatiya imi prostituciej: avtoref. diss. ... kand. yurid. nauk: 12.00.08. Moskva [in Russian].

Shalimov, E. E. (2007). Ugolovno-pravovye i kriminologicheskie problemy torgovli lyud'mi: avtoref. diss. ... kand. yurid. nauk: 12.00.08. Saratov [in Russian].

Panov, N.I. (1980). Kvalifikaciya prestuplenij, sovershaemyh putyom obmana. Har'kov: Yuridicheskij institut [in Russian].

Romanov, S.Iu. (1998). Obman yak sposib zlochynnoi diialnosti: avtoref. dys. ... kand. yuryd. nauk: 12.00.08. Kharkiv [in Ukrainian].

Maksymovych, R. (2019). Obman yak naskrizne kryminalno-pravove poniattia. Visnyk Lvivskoho universytetu. Seriia yurydychna, Vyp. 69, 153-160 [in Ukrainian].

Anisimov, H.M. (2003). Zlovzhyvannia doviroiu yak sposib vchynennia zlochynu: poniattia i kryminalno-pravove znachennia: avtoref. dys. ... kand. yuryd. nauk: 12.00.08. Kharkiv [in Ukrainian].

Anisimov, H.M. (2015). Zlovzhyvannia doviroiu yak sposib uchynennia zlochynu. Problemy zakonnosti, Vyp. 128, 20-28 [in Ukrainian].

Zahynei, Z.A. (2016). Hermenevtyka kryminalnoho zakonu Ukrainy: dys. ... dokt. yuryd. nauk: 12.00.08. Kyiv [in Ukrainian].

Zinchenko, I.O., Samoshchenko, I.V. (2006). Pro poniattia shantazhu v kryminalnomu pravi. Kryminalne pravo Ukrainy, 9, 3-8 [in Ukrainian].

Samoshchenko, I.V. (2019). Kharakterystyka shantazhu za kryminalnym pravom Ukrainy ta zarubizhnykh krain. Naukovyi visnyk Mizhnarodnoho humanitarnoho universytetu. Seriia: Yurysprudentsiia, Vyp. 39, 102-106 [in Ukrainian].

Ganchenko, O.I. (2011). Ponyatie shantazha v ugolovnom prave. Obshchestvo i pravo. 2011. № 5 (37). S. 163-165 [in Russian].

Izetov, A.E. (2010). Vtiahnennia u vchynennia terorystychnoho aktu: kryminalnopravove doslidzhennia. Kharkiv: Pravo [in Ukrainian].

Orlean, A. (2013). Vykorystannia urazlyvoho stanu yak forma vplyvu na osobu $\mathrm{z}$ metoiu yii ekspluatatsii: problemy teorii ta praktyky. Publichne pravo, 4 (12), 127-134 [in Ukrainian].

Kuznetsov, V.V. (2012). Kryminalno-pravova okhorona hromadskoho poriadku ta moralnosti v ukrainskomu vymiri. Kyiv: TOV NVP «Interservis» [in Ukrainian]. 
Synhaivska, I.V. (2019). Osoblyvosti rehlamentatsii kryminalnoi vidpovidalnosti za torhivliu liudmy. Vcheni zapysky Tavriiskoho natsionalnoho universytetu imeni V.I. Vernadskoho. Seriia: yurydychni nauky, Tom 30 (69), 1, 98-102 [in Ukrainian].

\author{
A. Andrushko, Doctor to of Law, Professor of the Department of Criminal Law \\ and Process, Uzhhorod National University \\ ORCID: 0000-0002-7735-7898
}

\title{
The material element of human trafficking
}

The article examines the problematic aspects of the material element of human trafficking and on this basis formulates proposals aimed at improving the current criminal law.

The article establishes that the purchase and sale of a child is most often classified as human trafficking. It is emphasized that the separation of child trafficking into a separate article of the Criminal Code of Ukraine is meaningless, because the relevant acts may well be qualified under Art. 149 of the Criminal Code of Ukraine.

It is argued that since trafficking in human beings is understood to mean its purchase and sale, this form of this crime should be called purchase and sale of a person, and not human trafficking.

The article criticizes the exclusion by legislators in September 2018 of "implementation of another illegal agreement, the object of which is a person" from the description of the material element of the crime, the responsibility for which is provided in Art. 149 of the Criminal Code of Ukraine.

It is substantiated in the article that the movement of a person should be understood not only as his or her actual transportation, but also organizational actions aimed at the movement.

It is established that the legal literature manifests difficulties in understanding the essence of such forms of human trafficking as the transfer or receipt of a person. It is emphasized that the transfer and receipt of a person as separate forms of trafficking in human beings have nothing to do with the sale or purchase of a person or other illegal agreements as regards a person. Art. 149 of the Criminal Code of Ukraine provides for liability for the transfer or receipt of a person, if they are committed in one of the ways provided for in this article, as well as for the purpose of human exploitation.

It has been established that in judicial practice the use of vulnerable status of the victim is most often recognized as a method of human trafficking, while deception is somewhat less common (usually these methods are combined).

The article recognizes as an unsubstantiated the opinion expressed in the legal literature about the expediency of a complete refusal to indicate in the disposition of Part 1 of Art. 149 of the Criminal Code of Ukraine on methods of human trafficking in the form of recruitment, transfer, concealment, ttoransfer or receipt of a person. It is due to deception, blackmail, being in a vulnerable state, etc. a person gives his or her consent to the job offer, to engagement in prostitu- 
tion, etc., and in view of this, and also in view of the purpose of further exploitation, even his or her voluntary consent does not exclude criminal liability of a perpetrator.

Keywords: criminal offenses against the freedom, honor and dignity of the person; human trafficking; the material element of the criminal offense; vulnerable state. 